\title{
Macrocyclization of Unprotected Peptide Isocyanates
}

Alexander A. Vinogradov, Zi-Ning Choo, Kyle A. Totaro, and Bradley L. Pentelute

Department of Chemistry, Massachusetts Institute of Technology, 18-596, 77 Massachusetts Avenue, Cambridge, Massachusetts, 02139, United States.

\section{Supporting Information}

\section{Contents}

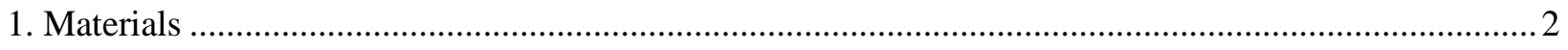

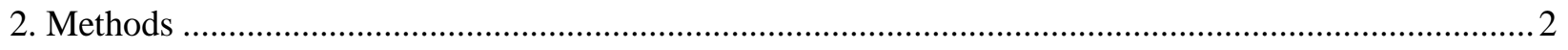

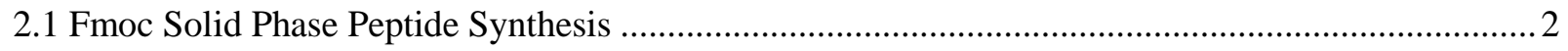

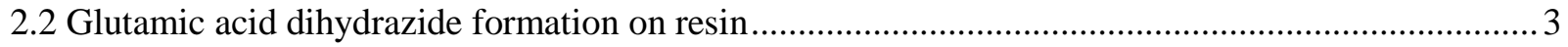

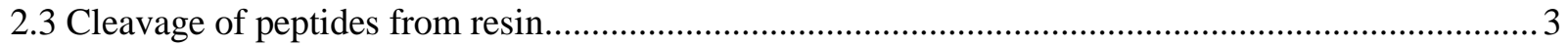

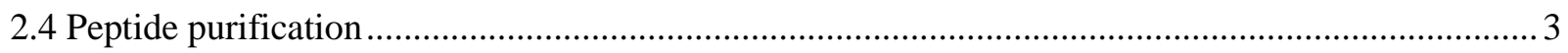

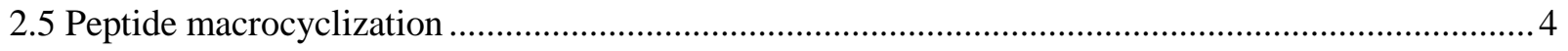

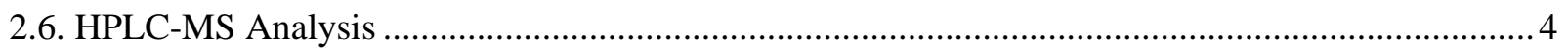

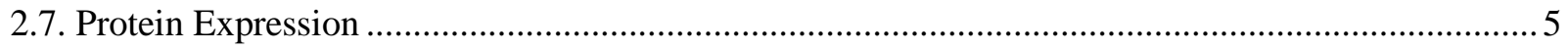

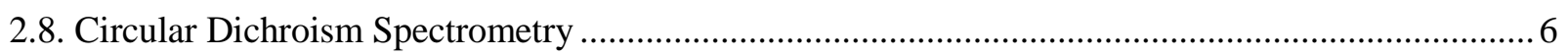

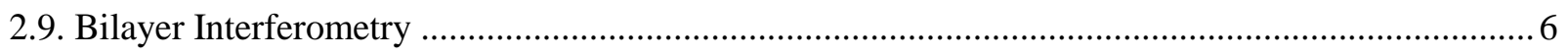

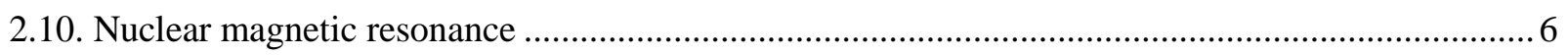

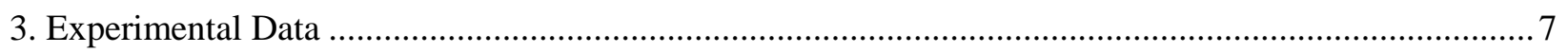

3.1. Synthesis of Glutamic Acid $\gamma$-hydrazides on Resin ................................................................. 7

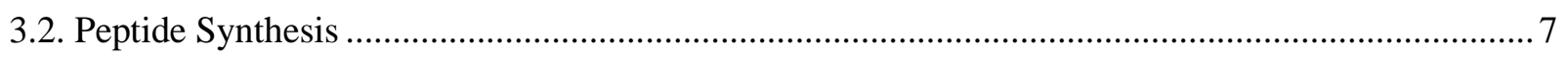

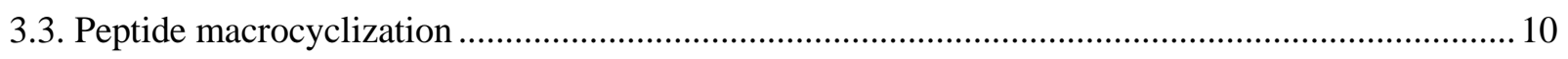

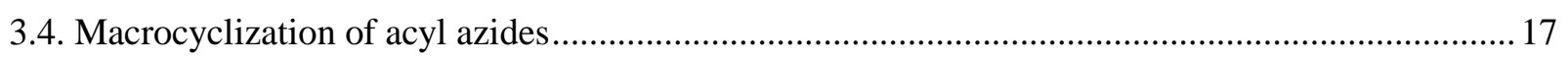

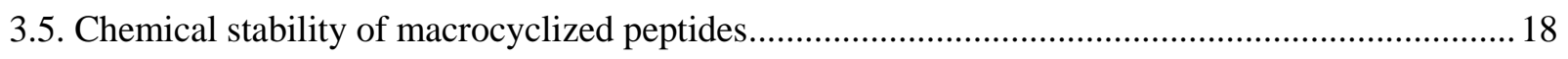

3.6 Proteolytic stability of macrocyclized peptides ......................................................................... 19

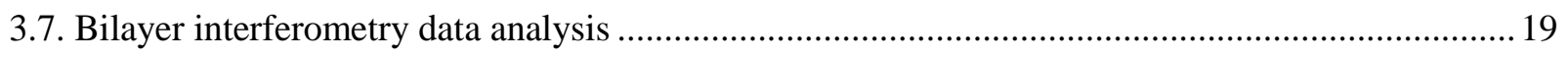

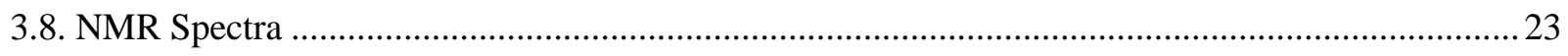




\section{Materials}

2-(1H-Benzotriazol-1-yl)-1,1,3,3-tetramethyluronium hexafluorophosphate (HBTU), 2-(7-Aza-1Hbenzotriazole-1-yl)-1,1,3,3-tetramethyluronium hexafluorophosphate (HATU), and Fmoc-L-Glu(All)-OH were purchased from Chem-Impex International. $\mathrm{N}^{\alpha}$-Fmoc protected L-amino acids were obtained through Advanced ChemTech, and Novabiochem. Boc-Gly-OH and Boc-Ile-OH were from Midwest Bio-Tech.

H-Rink Amide-ChemMatrix resin (100-200 mesh, $0.45 \mathrm{mmol} / \mathrm{g}$ loading) was purchased from PCAS BioMatrix Inc. 2-chlorotrityl chloride resin (200-400mesh, $1.2 \mathrm{mmol} / \mathrm{g}$ ) was purchased from Chem-Impex International and was subsequently used to prepare 2-chlorotrityl hydrazine resin adhering to the protocol reported by Stavropoulos, George et al. Letters in Peptide Science, 1995, 2, 315-318. The loading of the hydrazide resin was determined to be $0.75 \mathrm{mmol} / \mathrm{g}$.

N,N-Dimethylformamide (DMF), dichloromethane (DCM), diethyl ether, and HPLC-grade acetonitrile were from EMD Millipore. Triisopropyl silane (TIPS), and 1,2-Ethanedithiol (EDT) were from Alfa Aesar. Solvents for HPLC-MS were purchased from Fluka. All other reagents were purchased from Sigma-Aldrich. Unless specified, all reagents were used as received.

\section{Methods}

\subsection{Fmoc Solid Phase Peptide Synthesis}

Peptides were synthesized with the manual version of the flow-based peptide synthesis platform previously described (Simon, Heider et al. ChemBioChem, 2014, 15, 713-720). 200 mg H-Rink Amide ChemMatrix resin was used to synthesize all peptides except for peptide $\mathbf{3}$, for which $200 \mathrm{mg}$ 2-chlorotrityl hydrazide resin was used. During synthesis, all solvents and reagents were preheated to $60^{\circ} \mathrm{C}$ immediately before entering the synthesis vessel. The following 120 -second cycle was used to synthesize all peptides:

- Amide bond formation (coupling): 40 seconds at $6 \mathrm{~mL} / \mathrm{min}$

- Removal of coupling reagent (wash): 30 seconds at $20 \mathrm{~mL} / \mathrm{min}$

- $\quad \mathrm{N}^{\alpha}$-Fmoc removal (deprotection): 20 seconds at $20 \mathrm{~mL} / \mathrm{min}$

- Removal of deprotection reagent and products (wash): 30 seconds at $20 \mathrm{~mL} / \mathrm{min}$

Coupling. Coupling solution, consisting of $0.4 \mathrm{M} \mathrm{N}^{\alpha}$-Fmoc and side chain protected amino acid dissolved in 0.38 M HATU in DMF, was delivered at $6 \mathrm{~mL} / \mathrm{min}$ for 30 seconds and left in the reactor for an additional 10 seconds. The amino acid was activated with $500 \mu \mathrm{L}$ of DIEA two minutes prior to delivery.

When coupling any valine or isoleucine residues, synthesis was paused for 10 minutes following delivery. Increased reaction time was necessary to quantitatively couple these sterically hindered residues. 
Side chain protection was as follows: $\operatorname{Arg}(\mathrm{Pbf}), \mathrm{Asn}(\mathrm{Trt}), \mathrm{Asp}(\mathrm{OtBu}), \mathrm{Cys}(\mathrm{Trt}), \mathrm{Gln}(\mathrm{Trt}), \mathrm{Glu}(\mathrm{OAll})$, $\mathrm{Glu}(\mathrm{OtBu}), \operatorname{His}(\mathrm{Trt}), \mathrm{Lys}(\mathrm{Boc}), \operatorname{Ser}(\mathrm{tBu}), \operatorname{Thr}(\mathrm{tBu}), \operatorname{Trp}(\mathrm{Boc}), \operatorname{Tyr}(\mathrm{tBu})$. In addition, the N-terminus amino acid of each peptide was $\mathrm{N}^{\alpha}$-Boc protected to prevent guanidinylation by HBTU during side-chain hydrazide formation.

Wash. Excess reagent and reaction by-products were washed out from the synthesis vessel with $10 \mathrm{~mL}$ of DMF delivered at $20 \mathrm{~mL} / \mathrm{min}$ over $30 \mathrm{~s}$.

Deprotection. $\mathrm{N}^{\alpha}$-Fmoc protecting groups were removed with $6.6 \mathrm{~mL}$ of $20 \%(\mathrm{v} / \mathrm{v})$ piperidine in DMF delivered at $20 \mathrm{~mL} / \mathrm{min}$ over 20 seconds.

\subsection{Glutamic acid dihydrazide formation on resin}

$\gamma$-Allyl ester of glutamic acid was removed on resin with 0.2 equivalents (relative to the loading of the resin) of $\mathrm{Pd}\left(\mathrm{PPh}_{3}\right)_{4}$ and 20 equivalents of phenylsilane in $\mathrm{DCM}$ at room temperature for 20 minutes in a glass synthesis vessel. After draining the deprotection reagents, the resin was washed three times each with DCM and DMF, and the resulting carboxylic acid was activated with 5 equivalents a $0.38 \mathrm{M}$ solution of HBTU in DMF and 2 equivalents of DIEA for two minutes. The resin was washed with DMF three times, and then a $0.5 \mathrm{M}$ solution of hydrazine in DMF was added to the resin. The coupling was allowed to proceed for 30 minutes at room temperature, and then the resin was washed three times each with DMF and then DCM.

\subsection{Cleavage of peptides from resin}

All peptides were cleaved from the resin and side chain deprotected with a standard cleavage cocktail of $2.5 \%(\mathrm{v} / \mathrm{v})$ EDT, $2.5 \%(\mathrm{v} / \mathrm{v}) \mathrm{H}_{2} \mathrm{O}$, and $1 \%(\mathrm{v} / \mathrm{v})$ TIPS in TFA for 7 minutes at $60{ }^{\circ} \mathrm{C}$. In all cases, compressed nitrogen was used to evaporate the cleavage solution to dryness after filtering the resin. The resulting mixtures were washed three times with cold diethyl ether, dissolved in $50 \%$ water / 50\% acetonitrile $(0.1 \%$ TFA added) and lyophilized.

\subsection{Peptide purification}

All peptides were purified by RP-HPLC on a Waters 600 HPLC system with a Waters 484 or 486 UV detector using water with $0.1 \%$ TFA added (solvent A) and acetonitrile with $0.1 \%$ TFA added (solvent B) as solvents.

An Agilent Zorbax 300SB preparative C3 column (300 ̊, $7 \mu \mathrm{m}, 21.2$ x $250 \mathrm{~mm}$ ) was used for purification of preparative scale syntheses of peptide $\mathbf{1}$ and peptides 1a-1d. The following gradient was used at a flow rate of $20 \mathrm{~mL} / \mathrm{min}$ : 5\% B in A for 10 minutes, followed by 5\%-10\% B ramping linearly over 
5 minutes, and 10\%-50\% B ramping linearly over 120 minutes. Fractions were collected and screened for the desired material using HPLC-ESI-TOF.

An Agilent Zorbax 300SB semi-preparative C3 column (300 ̊, $5 \mu \mathrm{m}, 9.4$ x $250 \mathrm{~mm}$ ) was used for purification of all other peptides with the following gradient at a flow rate of $5 \mathrm{~mL} / \mathrm{min}$ to purify all other peptides: 5\% B in A for 5 minutes, then 5\%-35\% B ramping linearly over 120 minutes. Fractions were collected and screened for the desired material using HPLC-ESI-TOF.

\subsection{Peptide macrocyclization}

Unless noted, macrocyclization reactions were performed under the following standard conditions: 3.07 $\mathrm{mM}$ peptide hydrazide solution in oxidation buffer $\left(200 \mathrm{mM} \mathrm{Na} 2 \mathrm{HPO}_{4}\right.$ and $6 \mathrm{M} \mathrm{Gn} \cdot \mathrm{HCl}$ in water, $\mathrm{pH} 3.0$ 3.2) was incubated in an ice-salt bath at $-15^{\circ} \mathrm{C}$ for $5 \mathrm{~min}$. Then, $200 \mathrm{mM} \mathrm{NaNO}$ solution in water was carefully added to the peptide to a final $\mathrm{NaNO}_{2}$ concentration of $18 \mathrm{mM}$. The reaction was allowed to proceed for 10 minutes at $-10{ }^{\circ} \mathrm{C}$. Then, a $5 \mathrm{mM}$ solution of bifunctional nucleophile in water/acn $(1: 3, \mathrm{v} / \mathrm{v}$, 0.1\% TFA added, $\mathrm{pH} \sim 2.5-3.5$ depending on the nucleophile) was added to the reaction mixture to a final peptide concentration of $80-100 \mu \mathrm{M}$ and the mixture was thermostated at $70{ }^{\circ} \mathrm{C}$ for 10 minutes.

Preparative scale reactions were performed in a similar manner unless otherwise noted. Crude reaction mixtures were frozen down in liquid nitrogen, lyophilized, redissolved in 95\% A/5\% B and purified essentially following the protocol from section 2.4.

\subsection{HPLC-MS Analysis}

Unless noted, all peptides, proteins and reaction mixtures were analyzed on an Agilent 6520 Accurate Mass Q-TOF LC-MS using an Agilent Zorbax 300SB C3 column (300 A, $5 \mu \mathrm{m}, 2.1$ x $150 \mathrm{~mm}$ ) run with the following method. At $40{ }^{\circ} \mathrm{C}$ and a flow rate of $0.8 \mathrm{~mL} / \mathrm{min}$, the following gradient was used: $1 \%$ acetonitrile with $0.1 \%$ formic acid added (FA, solvent B') in water with $0.1 \% \mathrm{FA}$ (solvent $\mathrm{A}^{\prime}$ ) for $2 \mathrm{~min}$, $1-61 \% \mathrm{~B}^{\prime}$ in A' ramping linearly over $11 \mathrm{~min}, 61 \% \mathrm{~B}$ ' in A' for 1 minute. Typically, $100-1000 \mu \mathrm{g} / \mathrm{mL}$ solutions of peptides and proteins were subject to analysis. More concentrated solutions were diluted to appropriate concentrations with $50 \% \mathrm{~A} / 50 \% \mathrm{~B}$. Unless noted, all chromatograms shown in this work are plots of total ion current (TIC) versus time. HPLC yields of reactions were calculated via manual integration of the area under peaks corresponding to reaction products. The data were analyzed using Agilent MassHunter Qualitative analysis software. All MS deconvolution spectra were obtained using the maximum entropy algorithm. 


\subsection{Protein Expression}

Full-length HIV1 Core Antigen was obtained from Invitrogen. C-CA sequence was cloned into pETSUMO plasmid and ligated with T4 ligase overnight at $4{ }^{\circ} \mathrm{C}$. The resulting construct was transformed into DH5 $\alpha$ cells and then purified with the QIAprep Spin Miniprep Kit. BL21 DE3 competent cells were transformed via heat shock with $100 \mathrm{ng}$ of plasmid containing properly oriented C-CA inserts. Single transformed colonies were grown in $1 \mathrm{~L} \mathrm{LB}$ broth containing $30 \mu \mathrm{g} / \mathrm{mL}$ kanamycin. The cultures were induced with $1 \mathrm{~mL} 0.4 \mathrm{M}$ IPTG upon reaching $\mathrm{OD}_{600}=0.6$.

Following overnight expression, cells were pelleted and resuspended in $50 \mathrm{~mL}$ Tris buffer (50 mM Tris, $150 \mathrm{mM} \mathrm{NaCl}, \mathrm{pH}$ 7.4) containing $20 \mathrm{mg}$ lysozyme, $2 \mathrm{mg}$ DNAse I, and a half tablet cOmplete Mini protease inhibitor cocktail (Roche Life Science). Following sonication, the suspension was pelleted (25 minutes, $17000 \mathrm{rpm}$ ) and supernatant loaded onto a Ni-NTA column (HisTrap FF crude, GE Healthcare). The column was washed with $30 \mathrm{~mL}$ each of Tris buffer $(\mathrm{pH} 8.0)$ and $40 \mathrm{mM}$ imidazole in Tris buffer $(\mathrm{pH}$ 8.0) and the SUMO-CCA fusion protein was eluted in $10 \mathrm{~mL} 150 \mathrm{mM}$ imidazole in Tris buffer (pH 8.0). The protein was then subject to buffer exchange on Akta FPLC into Tris buffer at pH 7.4.

Protein concentration was determined by measuring absorbance at $280 \mathrm{~nm}(\mathrm{MW}=22916.9 \mathrm{Da}, \varepsilon=9970$ as found on ExPASy ProtParam (http://web.expasy.org/protparam/)); SUMO cleavage was subsequently performed by incubating SUMO-CCA overnight at $4^{\circ} \mathrm{C}$ with $1 \mathrm{ng}$ SUMO protease per $1 \mathrm{mg}$ protein. The resulting mixture was loaded onto a Ni-NTA column and washed with $10 \mathrm{~mL} 40 \mathrm{mM}$ imidazole in Tris buffer ( $\mathrm{pH}$ 8.0) to isolate C-CA. The protein was subjected to buffer exchange into Tris buffer at $\mathrm{pH}$ 7.4, concentrated over a 3000 Da Amicon Ultra-15 Centrifugal Filter Unit (EMD Millipore), analyzed by HPLC-MS (Fig. S1), and flash frozen in liquid nitrogen for long-term storage at $-80{ }^{\circ} \mathrm{C}$.

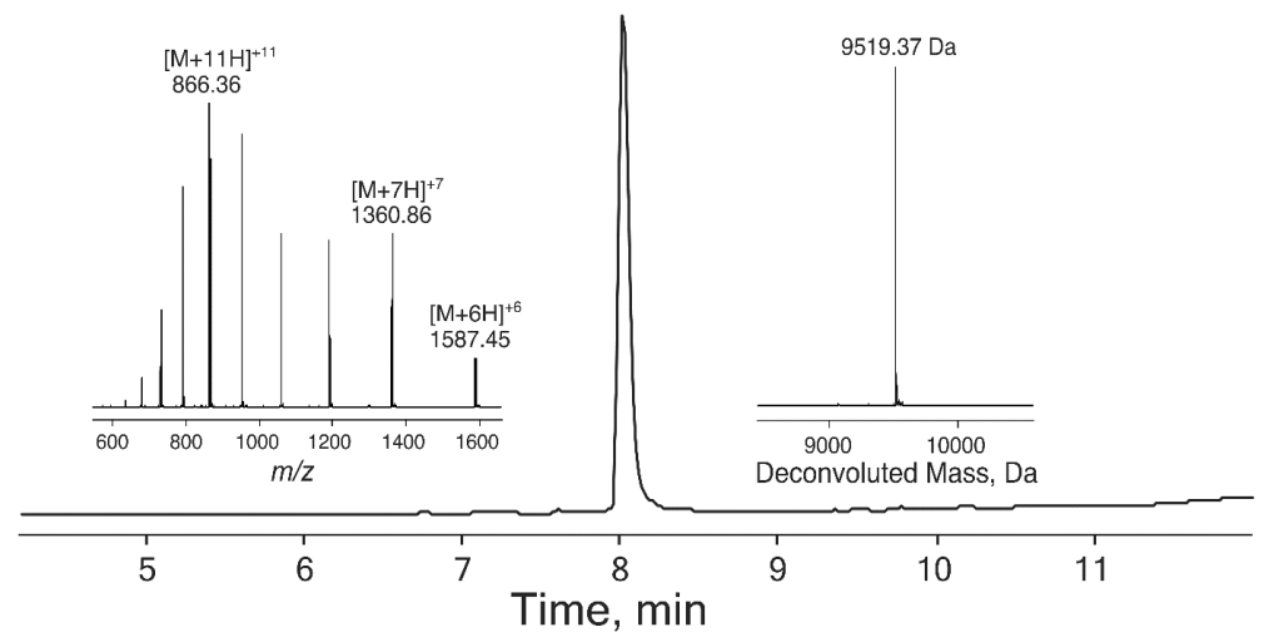

Figure S1. HPLC-MS (TIC chromatogram with MS insets and MS deconvolution result) characterization of recombinant CCA. Calculated molecular weight: $9518.9 \mathrm{Da}$ 


\subsection{Circular Dichroism Spectrometry}

All CD spectra were acquired on an Aviv 202 Circular Dichroism Spectrometer in a $1 \mathrm{~mm}$ quartz cuvette from 260 to $190 \mathrm{~nm}$ with fifteen-second averaging times at each wavelength. $0.5 \mathrm{mg} / \mathrm{mL}$ peptide solutions were prepared by dissolving solid samples in a $25 \%$ acetonitrile / $75 \%$ phosphate buffer $\left(50 \mathrm{mM} \mathrm{NaSO}_{4}\right.$, $20 \mathrm{Na}_{2} \mathrm{HPO}_{4}, \mathrm{pH}$ 7.4). Data processing included solvent background correction (subtraction) and adjustment for pathlength and concentration (mean residue ellipticity, $M R E=[\theta] \lambda=\frac{\theta_{\text {obs }}}{10 l c n}$, where $\theta_{\text {obs }}$ is measured ellipticity, $\theta$ - mean residual ellipticity in $\mathrm{deg} \cdot \mathrm{cm}^{2} \cdot \mathrm{dmol}^{-1}, l$ - pathlength in $\mathrm{cm} ; c-$ concentration of peptide in $\mathrm{M} ; n-\#$ of amino acids). $\alpha$-helicities of the peptides were estimated using previously established methods (Muppidi, Doi et al, J. Am. Chem. Soc. 2012, 134, 14734-14737).

\subsection{Bilayer Interferometry}

Binding kinetics for the C-CA/NYAD-1 interaction were measured on Octet RED96 instrument from ForteBio. All measurements were performed at $30^{\circ} \mathrm{C}$ in a $96-w e l l$ plate shaking at $1000 \mathrm{rpm}$. In general, streptavidin-coated tips (from ForteBio) were dipped in binding buffer (1x phosphate buffered saline, 1\% w/v bovine serum albumin, $0.02 \%$ tween-20, $\mathrm{pH} 7.4$ ) for 10 minutes to remove sucrose coating. A typical experiment consisted of five steps:

- Base line reading. Tips were dipped in a well containing fresh binding buffer for $60 \mathrm{sec}$.

- Ligand loading. $~ 100 \mu \mathrm{M}$ solutions of biotinylated NYAD-1 analogues in binding buffer were associated onto the tips for 90-300 seconds.

- Base line reading \#2. Tips were dipped in a well containing fresh binding buffer for 90-120 sec.

- Association. NYAD-1 loaded tips were dipped into well containing variable concentrations of CCA $(100 \mathrm{nM}-10 \mu \mathrm{M})$ in binding buffer for $90-300$ seconds.

- Dissociation. The tips were dipped back into wells containing binding buffer only for 300 seconds or until the response decreased back to the base line level.

Double referencing using wells containing no C-CA and tips loaded with no ligands was used to subtract the background. Collected data were analyzed manually as described in section 3.5.

\subsection{Nuclear magnetic resonance}

${ }^{1} \mathrm{H}$ NMR spectra were recorded on a Bruker Avance $600 \mathrm{MHz}$ spectrometer and are reported in ppm using solvent as an internal standard (DMSO- $d_{6}$ at $2.54 \mathrm{ppm}$ ). Data are reported as ( $\mathrm{s}=$ singlet, $\mathrm{d}=$ doublet, $\mathrm{dd}=$ doublet of doublets, $\mathrm{t}=$ triplet, $\mathrm{q}=$ quartet, $\mathrm{m}=$ multiplet, $\mathrm{br}=$ broad; coupling constant $(\mathrm{s}) \mathrm{in} \mathrm{Hz}$; integration). Proton-decoupled ${ }^{13} \mathrm{C}$ NMR spectra were recorded on a Bruker Avance $600 \mathrm{MHz}(150 \mathrm{MHz})$ spectrometer and are reported in ppm using solvent as an internal standard (DMSO- $d_{6}$ at $39.52 \mathrm{ppm}$ ). 


\section{Experimental Data}

\subsection{Synthesis of Glutamic Acid $\gamma$-hydrazides on Resin}

Representative analytical HPLC/MS data for the synthesis of hydrazides on resin following the procedure from section 2.2 are summarized in Fig. S2.

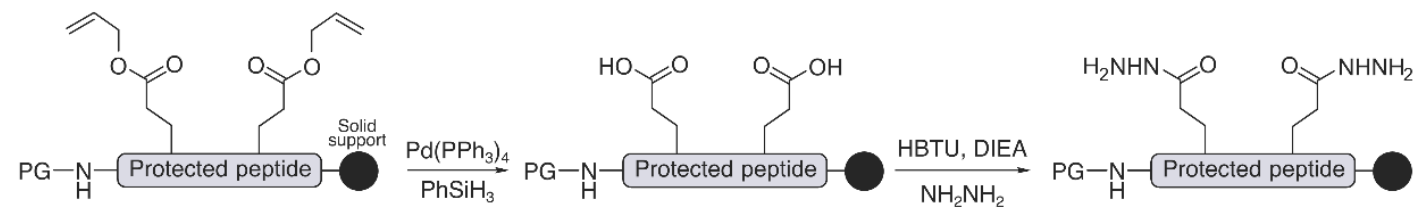

a)

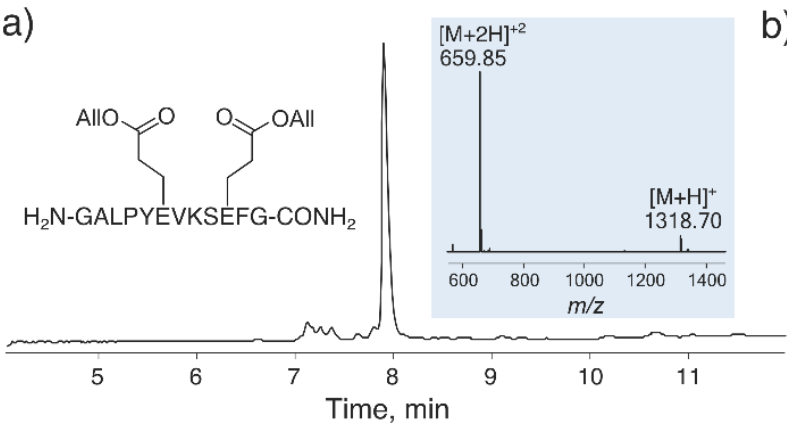

b)

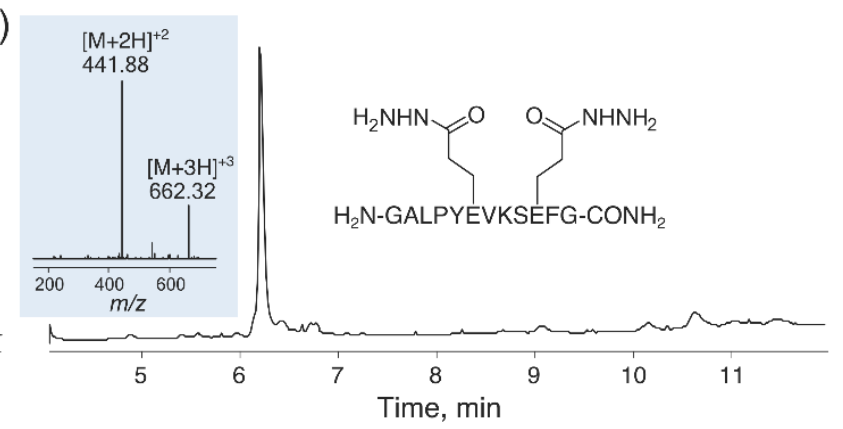

Figure S2. On resin synthesis of glutamic acid $\gamma$-hydrazides. a) HPLC-MS (TIC) chromatogram with MS inset for crude peptide 1 prior to allyl ester removal. b) HPLC-MS (TIC) chromatogram with MS inset for crude peptide $\mathbf{1}$ after allyl ester removal and hydrazine coupling.

\subsection{Peptide Synthesis}

\subsection{1. $\mathrm{H}_{2} \mathrm{~N}-\mathrm{Gly}$-Ala-Leu-Pro-Tyr-Glu(CONHNH$\left.{ }_{2}\right)$-Val-Lys-Ser-Glu(CONHNH 2$)$-Phe-Gly- $\mathrm{CONH}_{2}$}

The peptide (peptide 1 in the manuscript) was synthesized and purified as described above (Section 2). RP-HPLC purification of $138.8 \mathrm{mg}$ crude peptide yielded $19.8 \mathrm{mg}$ of pure peptide after lyophilization.

Additionally, the peptide was synthesized in batch at room temperature with Fmoc SPPS on $2.5 \mathrm{~g} \mathrm{H}-$ Rink Amide ChemMatrix resin with $0.45 \mathrm{mmol} / \mathrm{g}$ loading. Side chain and $\mathrm{N}$-terminus protecting groups were identical to those described previously. Amino acids were incorporated according to the cycle below, with the exception of the C-terminus glycine and the two glutamic acid residues, which were coupled for 90 minutes each:

- Amide bond formation (coupling): 45 minutes

- Removal of coupling reagent (wash): 5 one-minute washes 
- $\quad \mathrm{N}^{\alpha}$-Fmoc removal (deprotection): 3 two-minute washes

- Removal of deprotection reagent and products (wash): 5 one-minute washes

$5 \mathrm{mmol}$ of each amino acid was used per coupling, with the exception of the two glutamic acid residues, of which $3 \mathrm{mmol}$ was used. The coupling solution consisted of $0.4 \mathrm{M}$ amino acid dissolved in a $0.38 \mathrm{M}$ HATU solution in DMF; the amino acid was activated for two minutes with 1.7 eq. of DIEA prior to coupling. Glutamic acid dihydrazide formation on resin was performed as described in section 2.2. Peptide crude was subject to RP-HPLC purification, which yielded $480 \mathrm{mg}$ of pure peptide as a white powder after lyophilization. The peptide was isolated as a trifluoroacetic acid salt.

${ }^{1} \mathrm{H}$ NMR (600 MHz, DMSO- $\left.d_{6}\right): \delta 10.52(\mathrm{~s}, 2 \mathrm{H}), 8.53(\mathrm{~d}, J=7.4 \mathrm{~Hz}, 1 \mathrm{H}), 8.09-8.20(\mathrm{~m}, 8 \mathrm{H}), 7.98(\mathrm{~d}$, $J=6.6 \mathrm{~Hz}, 1 \mathrm{H}), 7.86-7.89(\mathrm{~m}, 4 \mathrm{H}), 7.79(\mathrm{~d}, J=7.2 \mathrm{~Hz}, 1 \mathrm{H}), 7.23-7.25(\mathrm{~m}, 5 \mathrm{H}), 7.19$ (d, $J=6.8 \mathrm{~Hz}$, $1 \mathrm{H}), 7.13(\mathrm{~s}, 1 \mathrm{H}), 7.01(\mathrm{~d}, J=8.1 \mathrm{~Hz}, 2 \mathrm{H}), 7.01(\mathrm{~d}, J=8.1 \mathrm{~Hz}, 2 \mathrm{H}), 6.62(\mathrm{~d}, J=8.1 \mathrm{~Hz}, 2 \mathrm{H}), 4.51-4.56$ $(\mathrm{m}, 2 \mathrm{H}), 4.36-4.42(\mathrm{~m}, 2 \mathrm{H}), 4.28-4.34(\mathrm{~m}, 4 \mathrm{H}), 4.18-4.22(\mathrm{~m}, 2 \mathrm{H}), 3.70(\mathrm{dd}, J=16.8,6.0 \mathrm{~Hz}, 1 \mathrm{H})$, $3.65(\mathrm{dd}, J=10.3,5.7 \mathrm{~Hz}, 1 \mathrm{H}), 3.60(\mathrm{~d}, J=5.1 \mathrm{~Hz}, 2 \mathrm{H}), 3.57(\mathrm{~s}, 2 \mathrm{H}), 3.54(\mathrm{~m}, 1 \mathrm{H}), 3.41-3.49(\mathrm{~s}, 1 \mathrm{H})$, $3.06(\mathrm{dd}, J=13.6,4.4 \mathrm{~Hz}, 1 \mathrm{H}), 2.90(\mathrm{~d}, J=10.5 \mathrm{~Hz}, 1 \mathrm{H}), 2.71-2.82(\mathrm{~m}, 4 \mathrm{H}), 2.22(\mathrm{~m}, 2 \mathrm{H}), 2.15(\mathrm{~m}, 2 \mathrm{H})$, $2.01(\mathrm{~m}, 1 \mathrm{H}), 1.89-1.97(\mathrm{~m}, 2 \mathrm{H}), 1.83(\mathrm{~m}, 4 \mathrm{H}), 1.71-1.78(\mathrm{~m}, 2 \mathrm{H}), 1.69(\mathrm{~m}, 1 \mathrm{H}), 1.62(\mathrm{~m}, 1 \mathrm{H}), 1.54(\mathrm{t}$, $J=6.9 \mathrm{~Hz}, 3 \mathrm{H}), 1.47(\mathrm{~m}, 1 \mathrm{H}), 1.21-1.40(\mathrm{~m}, 3 \mathrm{H}), 1.20(\mathrm{~d}, J=6.8 \mathrm{~Hz}, 3 \mathrm{H}), 0.90(\mathrm{~d}, J=6.6 \mathrm{~Hz}, 3 \mathrm{H}), 0.88$ $(\mathrm{d}, J=6.3 \mathrm{~Hz}, 3 \mathrm{H}), 0.84(\mathrm{~d}, J=6.6 \mathrm{~Hz}, 3 \mathrm{H})$.

${ }^{13} \mathrm{C}$ NMR (150 MHz, DMSO- $\left.d_{6}\right): \delta 172.03,171.72,171.67,171.65,171.58,171.54,171.49,171.43$, 171.38, 171.31, 171.11, 170.70, 165.83, 158.88 (d, $J=30.8$ Hz), 156.30, 138.08, 130.56, 129.57, 128.55, 127.97, 126.77, 118.50 (q, $J=299 \mathrm{~Hz}), 115.31,62.17,59.90,58.10,55.32,54.63,54.59,52.87,52.43$, 49.32 , 48.53, 47.12, 42.12, 40.58, 39.14, 37.64, 36.09, 31.59, 30.95, 30.03, 29.77, 29.13, 28.24, 27.73, $27.02,24.83,24.54,23.61,22.64,21.90,19.70,18.97,18.45$.

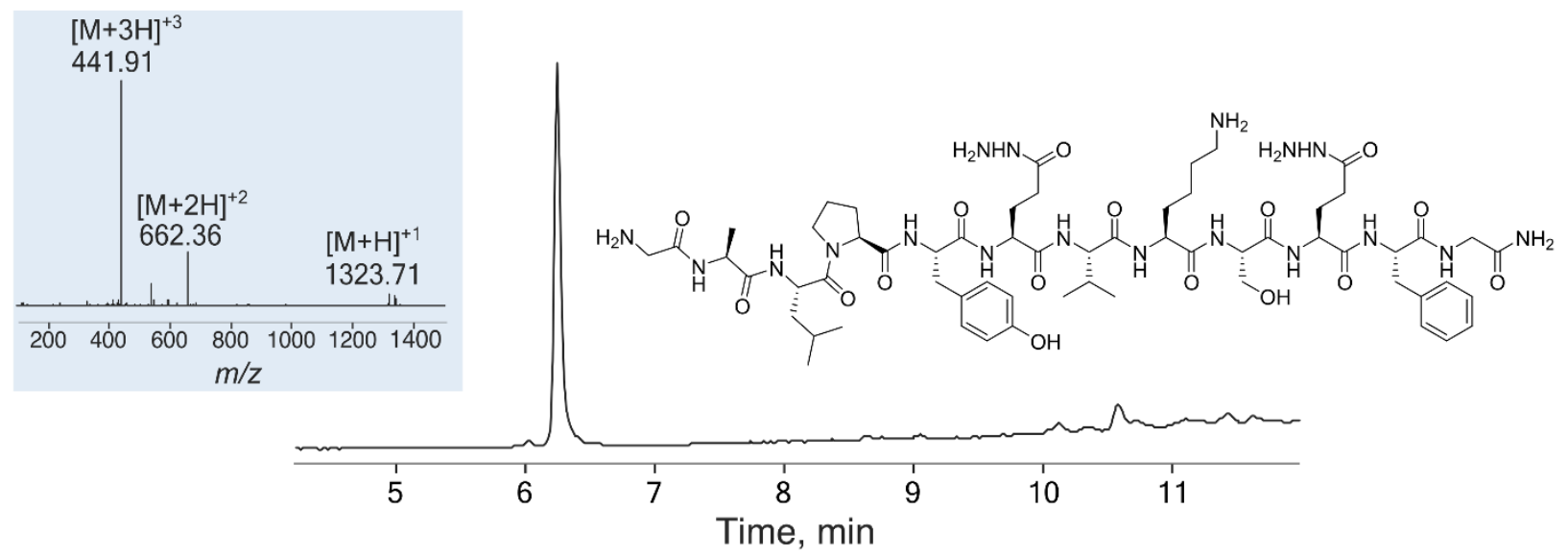

Figure S3. HPLC-MS (TIC) chromatogram for the purified peptide $\mathrm{H}_{2} \mathrm{~N}-\mathrm{Gly}$-Ala-Leu-Pro-Tyr-Glu(CONHNH 2$)-\mathrm{Val}_{2}-\mathrm{Lys}_{2}-\mathrm{Ser}-$ Glu(CONHNH 2$)-P h e-G l y-C O N H 2(1)$ with MS inset on the right. Calc. monoisotopic mass = 1322.71 Da. 


\subsection{2. $\mathrm{H}_{2} \mathrm{~N}-\mathrm{Gly}$-Ala-Glu(CONHNH$\left.{ }_{2}\right)$-Pro-Tyr-Leu-Val-Lys-Ser-Glu(CONHNH$\left.{ }_{2}\right)$-Phe-Gly-}

\section{$\mathrm{CONH}_{2}$}

The peptide (peptide 2 in the manuscript) was synthesized and purified as described above (Section 2). RP-HPLC purification of $111.3 \mathrm{mg}$ crude peptide yielded $8.0 \mathrm{mg}$ of pure peptide after lyophilization.

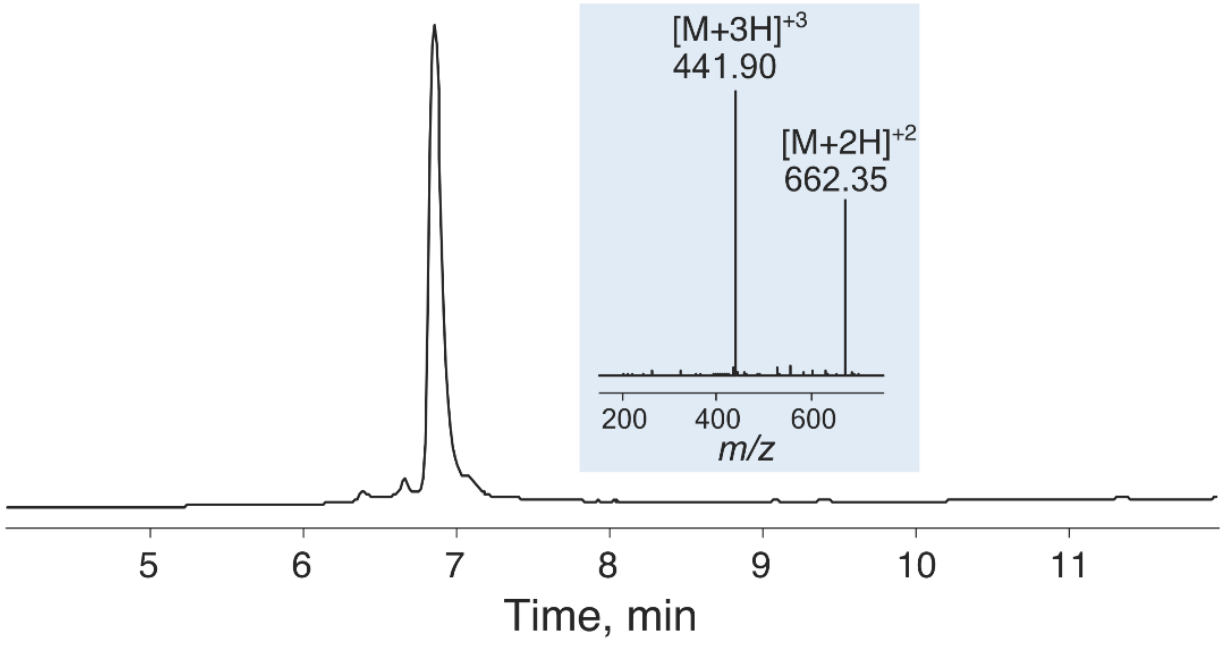

Figure S4. HPLC-MS (TIC) chromatogram for the purified peptide $\mathrm{H}_{2} \mathrm{~N}-\mathrm{Gly}-\mathrm{Ala}-\mathrm{Glu}\left(\mathrm{CONHNH} \mathrm{H}_{2}\right.$-Pro-Tyr-Leu-Val-Lys-Ser$\mathrm{Glu}\left(\mathrm{CONHNH}_{2}\right)-\mathrm{Phe}-\mathrm{Gly}-\mathrm{CONH}_{2}(2)$ with MS inset on the right. Calc. monoisotopic mass = 1322.71 Da.

\subsection{3. $\mathrm{H}_{2} \mathrm{~N}-\mathrm{Gly}$-Ala-Leu-Pro-Tyr-Glu( $\left.\mathrm{CONHNH}_{2}\right)$-Val-Lys-Ser-Glu(COOH)-Phe-Val-} $\mathrm{CONHNH}_{2}$

The peptide (peptide 3 in the manuscript) was synthesized and purified as described above (Section 2). RP-HPLC purification of $82.5 \mathrm{mg}$ crude peptide yielded $8.5 \mathrm{mg}$ of pure peptide after lyophilization.

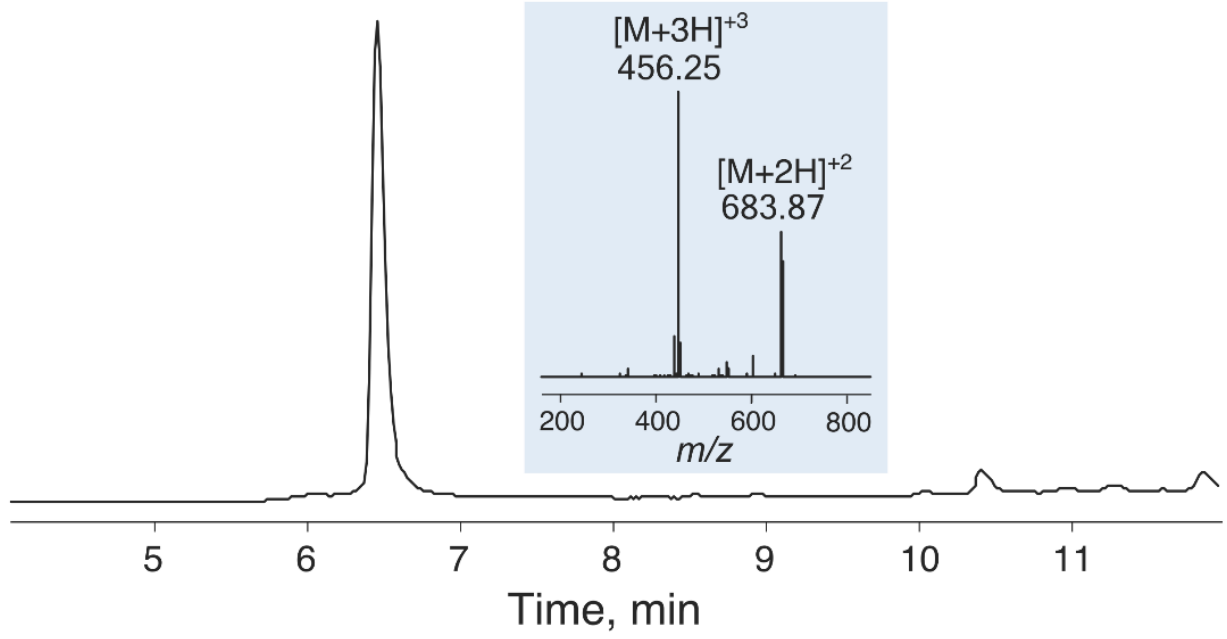

Figure S5. HPLC-MS (TIC) chromatogram for the purified peptide $\mathrm{H}_{2} \mathrm{~N}-\mathrm{Gly}$-Ala-Leu-Pro-Tyr-Glu(CONHNH 2$)-\mathrm{Cal}_{2}-\mathrm{Lys}_{\text {-Ser- }}$ Glu(COOH)-Phe-Val-CONHNH 2 (3) with MS inset on the right. Calc. monoisotopic mass = 1365.74 Da. 


\subsection{4. $\mathrm{H}_{2} \mathrm{~N}-\mathrm{Ile}-\mathrm{Thr}-\mathrm{Phe}-\mathrm{Glu}\left(\mathrm{CONHNH}_{2}\right)$-Asp-Leu-Leu-Glu(CONHNH 2$)$-Tyr-Tyr-Gly-Lys-Lys-}

Lys-Lys(biotin)- $\mathrm{CONH}_{2}$

The peptide (peptide $\mathbf{4}$ in the manuscript) was synthesized and purified as described above (Section 2). RP-HPLC purification of $240 \mathrm{mg}$ crude peptide yielded $37.6 \mathrm{mg}$ of pure peptide after lyophilization.

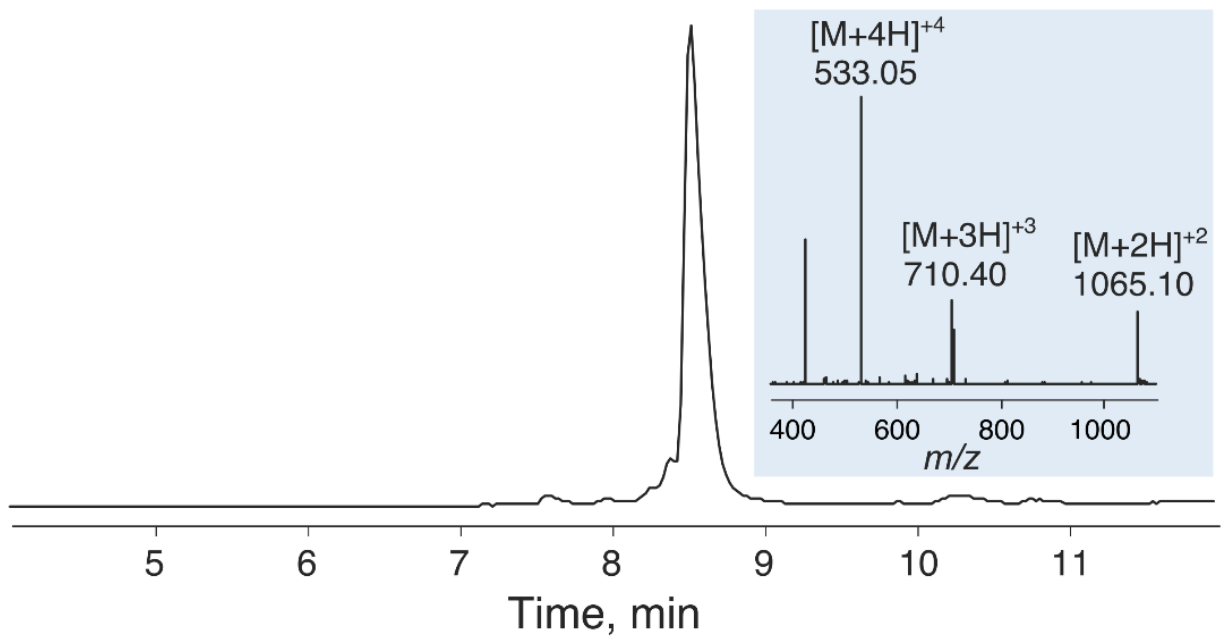

Figure S6. HPLC-MS (TIC) chromatogram for the purified peptide $\mathrm{H}_{2} \mathrm{~N}$-Ile-Thr-Phe-Glu(CONHNH )-Asp-Leu-LeuGlu(CONHNH 2$)-T y r-T y r-G l y-L y s-L y s-L y s-L y s\left(\right.$ biotin) $-\mathrm{CONH}_{2}$ (4) with $\mathrm{MS}$ inset on the right. Calc. monoisotopic mass = 2127.17 Da.

\subsection{Peptide macrocyclization}

\subsection{1. $\mathrm{H}_{2} \mathrm{~N}-\mathrm{Ile}-\mathrm{Thr}-\mathrm{Phe}-\mathrm{Glu}\left(\mathrm{CONHNH}_{2}\right)$-Asp-Leu-Leu-Glu(CONHNH $\left.\mathrm{C}_{2}\right)$-Tyr-Tyr-Gly-Lys-Lys-} Lys-Lys(biotin)- $\mathrm{CONH}_{2}$ cyclized with carbohydrazide

$9.4 \mathrm{mg}$ of peptide 4 were oxidized with sodium nitrite and cyclized with $5 \mathrm{mM}$ carbohydrazide as described in section 2.5. RP-HPLC purification of the crude reaction mixture yielded $1.3 \mathrm{mg}$ of pure $\mathbf{4 a}$ after lyophilization. 


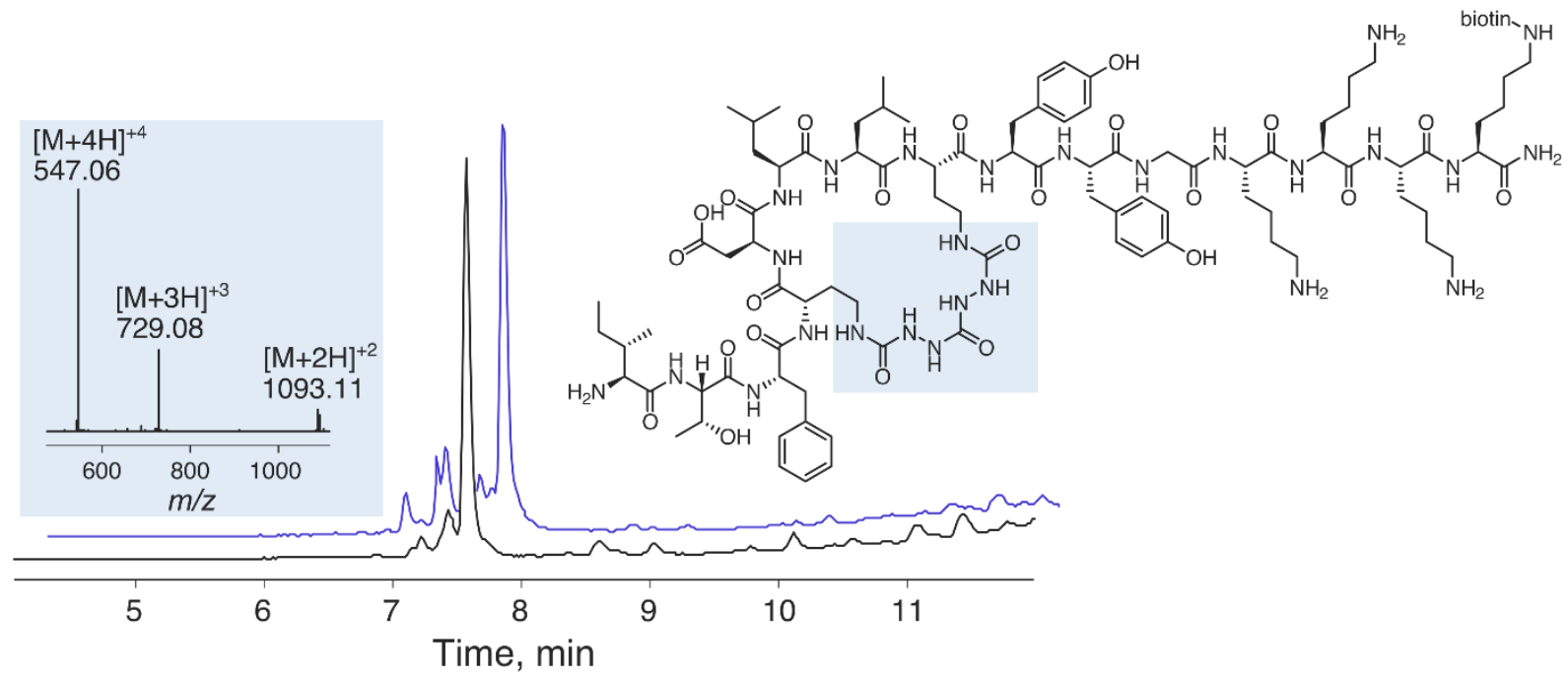

Figure S7. HPLC-MS (TIC) chromatogram for the crude and purified cyclized peptide 4a with MS inset on the left and the peptide structure on the right. The semicarbazide tether is highlighted. Crude macrocyclization reaction mixture chromatogram is shown in blue; purified product - in black. Calc. monoisotopic mass $=2183.19 \mathrm{Da}$.

\subsection{2. $\mathrm{H}_{2} \mathrm{~N}$-Ile-Thr-Phe-Glu(CONHNH 2$)$-Asp-Leu-Leu-Glu(CONHNH$\left.{ }_{2}\right)$-Tyr-Tyr-Gly-Lys-Lys-}

\section{Lys-Lys(biotin)- $\mathrm{CONH}_{2}$ cyclized with oxalyldihydrazide}

$9.4 \mathrm{mg}$ of peptide 4 were oxidized with sodium nitrite and cyclized with $5 \mathrm{mM}$ oxalyldihydrazide as described in section 2.5. RP-HPLC purification of the crude reaction mixture yielded $1.0 \mathrm{mg}$ of pure $\mathbf{4 b}$ after lyophilization.

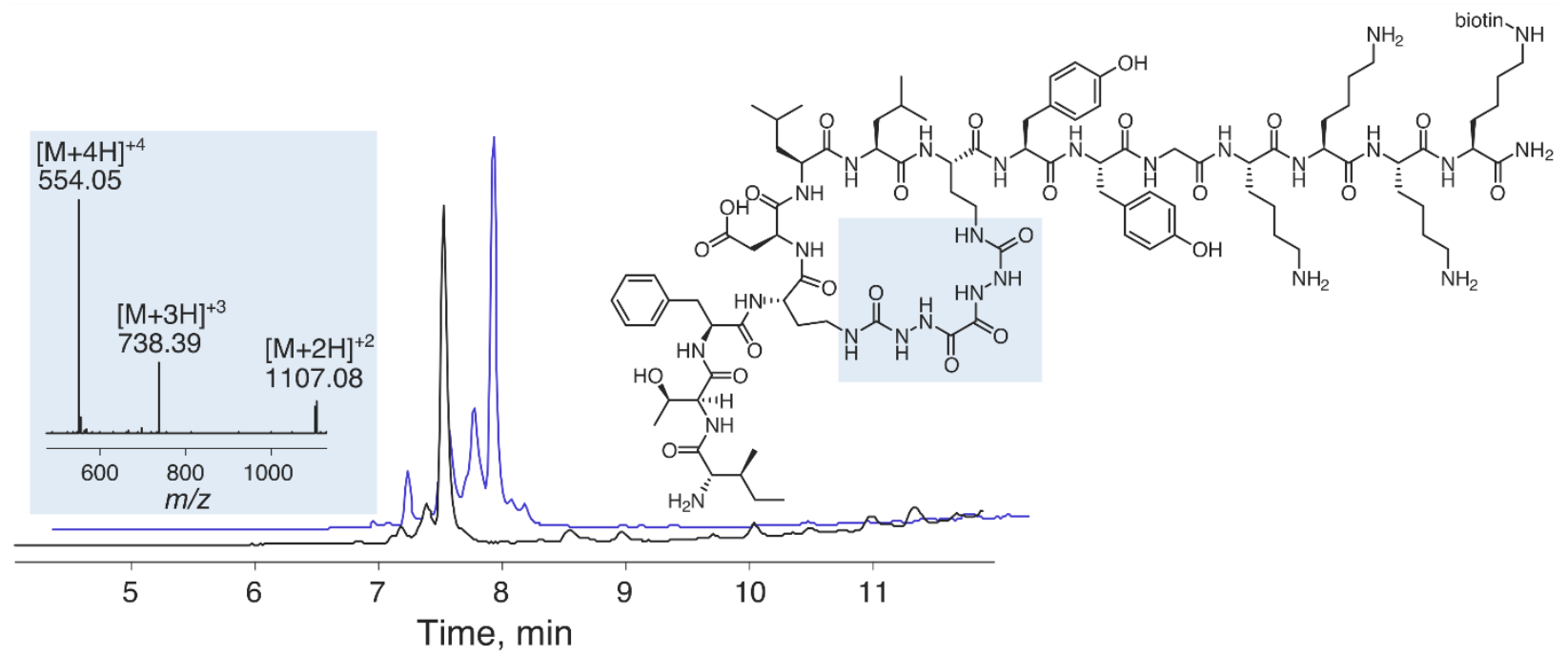

Figure S8. HPLC-MS (TIC) chromatogram for the crude and purified cyclized peptide with MS inset on the left and the peptide structure on the right. The semicarbazide tether is highlighted. Crude macrocyclization reaction mixture chromatogram is shown in blue; purified product — in black. Calc. monoisotopic mass = 2211.16 Da. 


\subsection{3. $\mathrm{H}_{2} \mathrm{~N}$-Ile-Thr-Phe-Glu( $\left.\mathrm{CONHNH}_{2}\right)$-Asp-Leu-Leu-Glu( $\left.\mathrm{CONHNH}_{2}\right)$-Tyr-Tyr-Gly-Lys-Lys-}

Lys-Lys(biotin)- $\mathrm{CONH}_{2}$ cyclized with succinic dihydrazide

$9.4 \mathrm{mg}$ of peptide $\mathbf{4}$ were oxidized with sodium nitrite and cyclized with $5 \mathrm{mM}$ succinic dihydrazide as described in section 2.5. RP-HPLC purification of the crude reaction mixture yielded $1.6 \mathrm{mg}$ of pure $\mathbf{4 c}$ after lyophilization.

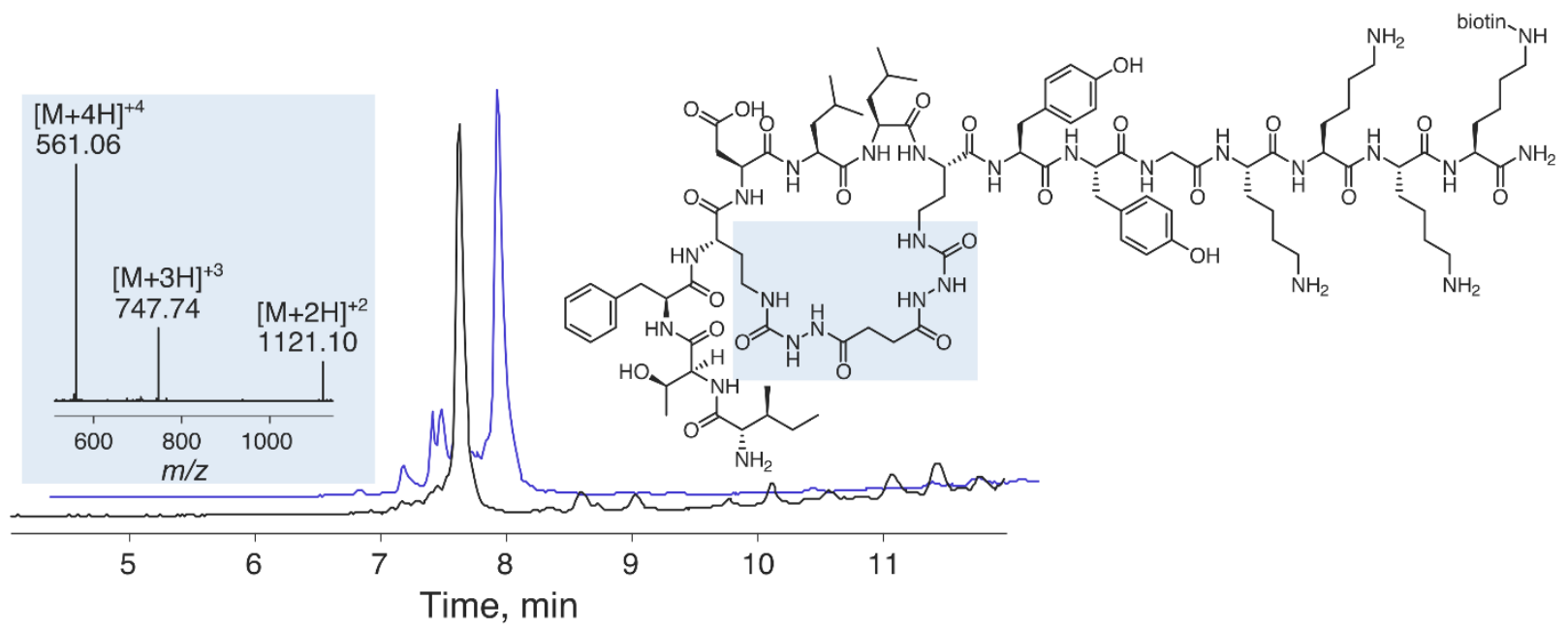

Figure S9. HPLC-MS (TIC) chromatogram for the crude and purified cyclized peptide $\mathbf{4 c}$ with MS inset on the left and the peptide structure on the right. The semicarbazide tether is highlighted. Crude macrocyclization reaction mixture chromatogram is shown in blue; purified product — in black. Calc. monoisotopic mass $=2239.19 \mathrm{Da}$.

\subsection{4. $\mathrm{H}_{2} \mathrm{~N}$-Ile-Thr-Phe-Glu( $\left.\mathrm{CONHNH}_{2}\right)$-Asp-Leu-Leu-Glu( $\left.\mathrm{CONHNH}_{2}\right)$-Tyr-Tyr-Gly-Lys-Lys-} Lys-Lys(biotin)- $\mathrm{CONH}_{2}$ cyclized with adipic acid dihydrazide

$9.4 \mathrm{mg}$ of peptide 4 were oxidized with sodium nitrite and cyclized with $5 \mathrm{mM}$ adipic acid dihydrazide as described in section 2.5. RP-HPLC purification of the crude reaction mixture yielded $1.3 \mathrm{mg}$ of pure $\mathbf{4 d}$ after lyophilization. 


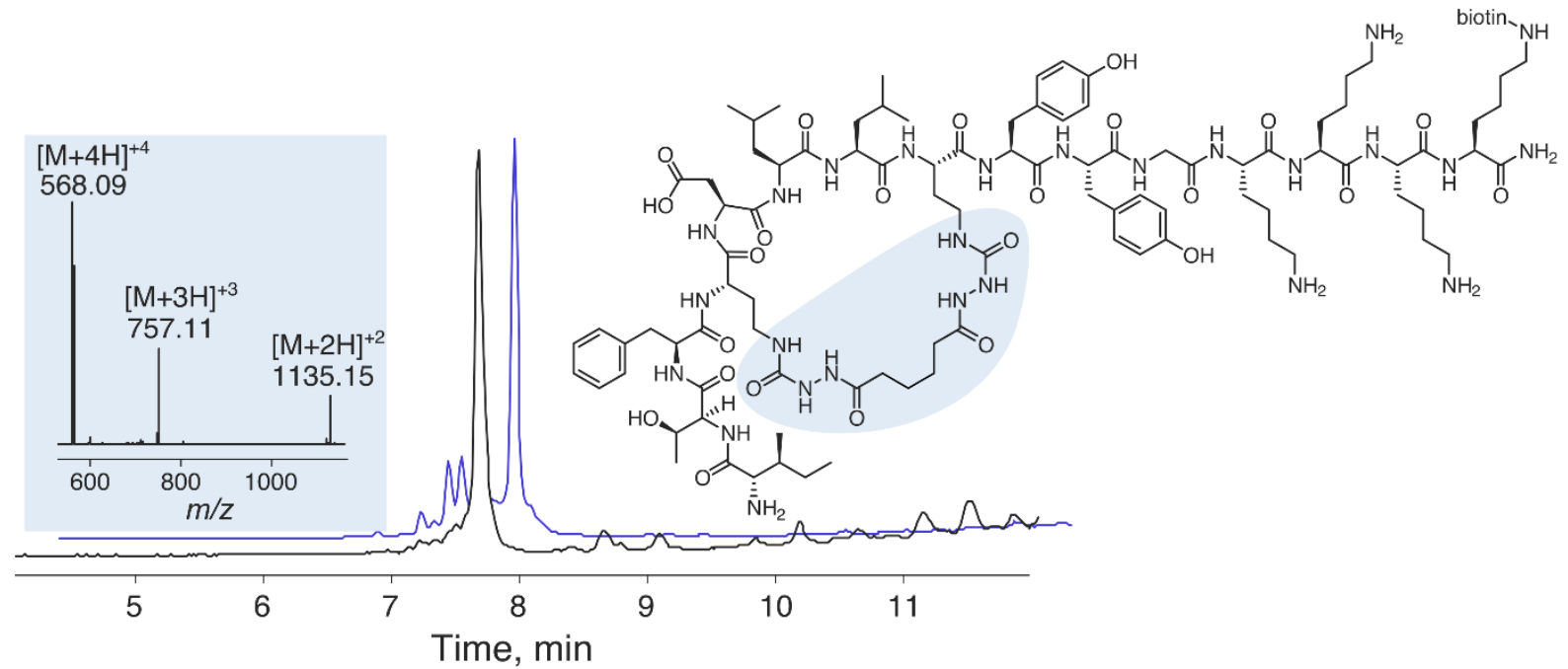

Figure S10. HPLC-MS (TIC) chromatogram for the crude and purified cyclized peptide 4d with MS inset on the left and the peptide structure on the right. The semicarbazide tether is highlighted. Crude macrocyclization reaction mixture chromatogram is shown in blue; purified product — in black. Calc. monoisotopic mass $=2267.22 \mathrm{Da}$.

\subsection{5. $\mathrm{H}_{2} \mathrm{~N}-\mathrm{Gly}$-Ala-Leu-Pro-Tyr-Glu(CONHNH$\left.{ }_{2}\right)$-Val-Lys-Ser-Glu(CONHNH 2$)-P h e-G l y-$ $\mathrm{CONH}_{2}$ cyclized with carbohydrazide}

$60.5 \mathrm{mg}$ of peptide 1 were dissolved in $14.9 \mathrm{~mL}$ of oxidation buffer, oxidized with $1.49 \mathrm{~mL}$ of $200 \mathrm{mM}$ sodium nitrite, and cyclized with $540.1 \mathrm{~mL}$ of $5 \mathrm{mM}$ carbohydrazide as described in section $2.5 .17 .0 \mathrm{~g}$ citrate was added to the reaction mixture and excess acetonitrile was removed with rotary evaporation. The cyclized peptide 1a was purified by RP-HPLC, yielding $15.4 \mathrm{mg}$ of the desired peptide as a white powder after lyophilization. The peptide was isolated as a trifluoroacetic acid salt.

${ }^{1} \mathrm{H}$ NMR (600 MHz, DMSO-d $\left.d_{6}\right): \delta 10.38$ (s, 1H), 10.35 (s, 1H), $8.51(\mathrm{~d}, J=7.2 \mathrm{~Hz}, 1 \mathrm{H}), 8.17-8.22$ $(\mathrm{m}, 2 \mathrm{H}), 8.08-8.12(\mathrm{~m}, 2 \mathrm{H}), 8.03(\mathrm{~s}, 5 \mathrm{H}), 7.90(\mathrm{~s}, 1 \mathrm{H}), 7.75-7.79(\mathrm{~m}, 3 \mathrm{H}), 7.71(\mathrm{~s}, 1 \mathrm{H}), 7.25(\mathrm{~m}, 4 \mathrm{H})$, $7.19(\mathrm{~m}, 1 \mathrm{H}), 7.14(\mathrm{~d}, J=11.9 \mathrm{~Hz}, 2 \mathrm{H}), 7.09(\mathrm{~m}, 1 \mathrm{H}), 7.00(\mathrm{~d}, J=6.8 \mathrm{~Hz}, 2 \mathrm{H}), 6.63$ (d, $J=6.9 \mathrm{~Hz}, 2 \mathrm{H})$, $6.45(\mathrm{~s}, 1 \mathrm{H}), 4.43-4.54(\mathrm{~m}, 2 \mathrm{H}), 4.36-4.42(\mathrm{~m}, 3 \mathrm{H}), 4.33(\mathrm{~m}, 2 \mathrm{H}), 4.22-4.27(\mathrm{~m}, 2 \mathrm{H}), 4.08$ - $4.15(\mathrm{~m}$, $1 \mathrm{H}), 3.68(\mathrm{dd}, J=16.4,5.4 \mathrm{~Hz}, 1 \mathrm{H}), 3.55-3.60(\mathrm{~m}, 6 \mathrm{H}), 3.45(\mathrm{~m}, 1 \mathrm{H}), 3.05-3.12(\mathrm{~m}, 2 \mathrm{H}), 2.92-3.02$ $(\mathrm{m}, 2 \mathrm{H}), 2.78-2.88(\mathrm{~m}, 3 \mathrm{H}), 2.75(\mathrm{~m}, 1 \mathrm{H}), 2.63-2.70(\mathrm{~m}, 2 \mathrm{H}), 2.08-2.10(\mathrm{~m}, 1 \mathrm{H}), 1.97(\mathrm{~s}, 1 \mathrm{H}), 1.84$ $(\mathrm{m}, 4 \mathrm{H}), 1.77(\mathrm{~m}, 1 \mathrm{H}), 1.68-1.72(\mathrm{~m}, 1 \mathrm{H}), 1.58-1.67(\mathrm{~m}, 2 \mathrm{H}), 1.50-1.57(\mathrm{~m}, 3 \mathrm{H}), 1.45-1.48(\mathrm{~m}, 2 \mathrm{H})$, $1.34-1.40(\mathrm{~m}, 1 \mathrm{H}), 1.24-1.32(\mathrm{~m}, 2 \mathrm{H}), 1.20(\mathrm{~d}, J=6.6 \mathrm{~Hz}, 3 \mathrm{H}), 0.87-0.91(\mathrm{~m}, 12 \mathrm{H})$.

${ }^{13} \mathrm{C}$ NMR (150 MHz, DMSO- $\left.d_{6}\right): \delta$ 172.08, 172.01, 171.77, 171.63, 171.58, 171.50, 171.37, 171.23, 171.16, 171.04, 170.49, 165.81, 159.50, 159.43, 159.36, 158.66 (d, $J=31.8$ Hz), 158.17, 158.07, 156.26, 
$138.15,130.57,129.63,128.56,129.97,126.76,117.47$ (d, $J=295.3 \mathrm{~Hz}), 115.29,62.18,61.91,61.29$, $59.88,55.70,55.24,54.86,54.59,51.73,51.44,51.12,50.99,49.28,48.51,47.11,42.49,42.45,40.60$, $39.24,37.67,37.08,36.89,36.68,29.18,27.06,27.03,24.83,24.54,23.65,22.43,21.89,19.88,19.76$, $19.70,19.02,18.45$.

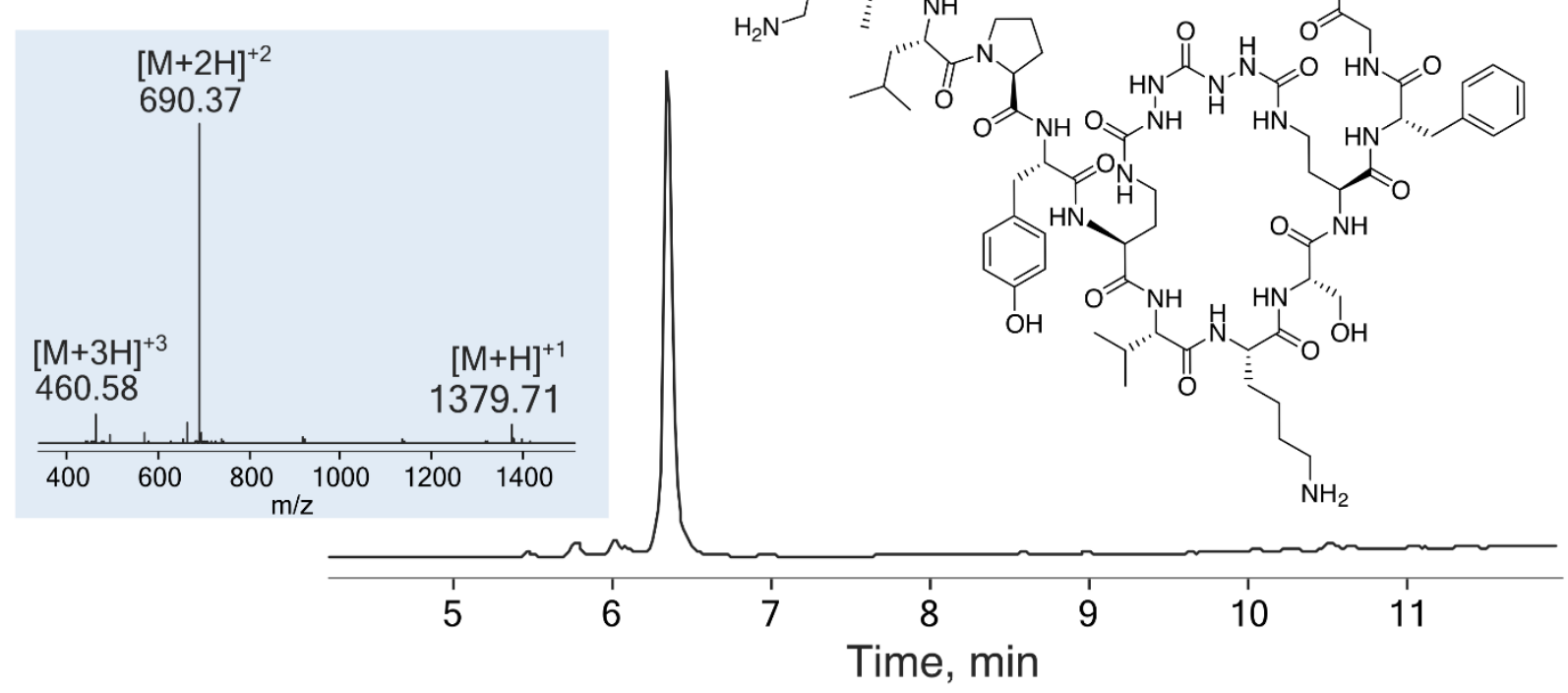

Figure S11. HPLC-MS (TIC) chromatogram for the purified cyclized peptide 1a with MS inset on the left and the peptide structure on the right. Calc. monoisotopic mass $=1378.71 \mathrm{Da}$.

\subsection{6. $\mathrm{H}_{2} \mathrm{~N}-\mathrm{Gly}$-Ala-Leu-Pro-Tyr-Glu(CONHNH$\left.{ }_{2}\right)$-Val-Lys-Ser-Glu(CONHNH 2$)-P h e-G l y-$} $\mathrm{CONH}_{2}$ cyclized with oxalyl dihydrazide.

$62.5 \mathrm{mg}$ of peptide 1 were dissolved in $15.4 \mathrm{~mL}$ of oxidation buffer, oxidized with $1.54 \mathrm{~mL}$ of $200 \mathrm{mM}$ sodium nitrite, and cyclized with $558 \mathrm{~mL}$ of $5 \mathrm{mM}$ oxalyl dihydrazide as described in section $2.5 .18 .5 \mathrm{~g}$ citric acid was added to the reaction mixture and excess acetonitrile was removed with rotary evaporation. The cyclized peptide 1b was purified by RP-HPLC, yielding $17.6 \mathrm{mg}$ of the desired peptide as a white powder after lyophilization. The peptide was isolated as a trifluoroacetic acid salt.

${ }^{1} \mathrm{H}$ NMR (600 MHz, DMSO-d $\left.d_{6}\right): \delta 10.38(\mathrm{~s}, 1 \mathrm{H}), 10.34(\mathrm{~s}, 1 \mathrm{H}), 8.51(\mathrm{~d}, J=7.4 \mathrm{~Hz}, 1 \mathrm{H}), 8.20(\mathrm{~d}, J=$ $7.6 \mathrm{~Hz}, 1 \mathrm{H}), 8.17(\mathrm{t}, J=5.7 \mathrm{~Hz}, 1 \mathrm{H}), 8.07-8.11(\mathrm{~m}, 2 \mathrm{H}), 8.03(\mathrm{~m}, 5 \mathrm{H}), 7.81-7.91(\mathrm{~m}, 2 \mathrm{H}), 7.71-7.76$ $(\mathrm{m}, 3 \mathrm{H}), 7.23-7.27(\mathrm{~m}, 4 \mathrm{H}), 7.13-7.20(\mathrm{~m}, 3 \mathrm{H}), 7.09(\mathrm{~s}, 1 \mathrm{H}), 7.00(\mathrm{~d}, J=8.1 \mathrm{~Hz}, 1 \mathrm{H}), 6.62(\mathrm{~d}, J=8.4$ $\mathrm{Hz}, 1 \mathrm{H}), 6.45$ (s, 1H), 5.10 (br. s, 1H), $4.44-7.50$ (m, 2H), $4.36-4.42$ (m, 3H), $4.31-4.34$ (m, 2H), 4.26 $-4.28(\mathrm{~m}, 1 \mathrm{H}), 4.17-4.24(\mathrm{~m}, 1 \mathrm{H}), 4.13(\mathrm{t}, J=7.0 \mathrm{~Hz}, 1 \mathrm{H}), 3.68(\mathrm{dd}, J=16.6,5.4 \mathrm{~Hz}, 1 \mathrm{H}), 3.50-3.65$ (m, 6H), $3.45(\mathrm{~s}, 1 \mathrm{H}), 3.10-3.13(\mathrm{~m}, 1 \mathrm{H}), 3.06(\mathrm{dd}, J=13.8,4.3 \mathrm{~Hz}, 1 \mathrm{H}), 2.81(\mathrm{~m}, 1 \mathrm{H}), 2.68-2.78(\mathrm{~m}$, $3 \mathrm{H}), 2.09(\mathrm{q}, J=6.6 \mathrm{~Hz}, 1 \mathrm{H}), 1.97(\mathrm{~m}, 1 \mathrm{H}), 1.81-1.86(\mathrm{~m}, 3 \mathrm{H}), 1.75-1.81(\mathrm{~m}, 2 \mathrm{H}), 1.68-1.74(\mathrm{~m}, 1 \mathrm{H})$, 
$1.59-1.66(\mathrm{~m}, 1 \mathrm{H}), 1.47-1.59(\mathrm{~m}, 4 \mathrm{H}), 1.46-1.48(\mathrm{~m}, 1 \mathrm{H}), 1.36-1.38(\mathrm{~m}, 1 \mathrm{H}), 1.27-1.32(\mathrm{~m}, 2 \mathrm{H})$, $1.20(\mathrm{~d}, J=7.0 \mathrm{~Hz}, 3 \mathrm{H}), 0.90(\mathrm{~d}, J=7.4 \mathrm{~Hz}, 3 \mathrm{H}), 0.98(\mathrm{~d}, J=6.8 \mathrm{~Hz}, 6 \mathrm{H}), 0.85$ (d, $J=6.6 \mathrm{~Hz}, 3 \mathrm{H})$.

${ }^{13} \mathrm{C}$ NMR (150 MHz, DMSO-d $): \delta$ 172.01, 171.91, 171.79, 171.64, 171.59, 171.51, 171.42, 171.27, 171.23, 171.07, 170.50, 165.81, 159.66, 159.60, 158.72 (d, $J=30.7 \mathrm{~Hz}), 158.18,158.10,156.26,138.13$, 130.59, 129.59, 128.56, 127.97, 126.77, 117.42 (d, $J=299.6$ Hz), 115.29, 61.92, 59.90, 58.71, 55.26, 54.78, 54.46, 52.92, 51.00, 49.28, 48.51, 47.12, 42.46, 40.60, 39.24, 37.69, 36.88, 36.68, 32.46, 31.19, 30.22, $29.16,27.03,24.83,24.54,23.65,22.43,21.90,19.87,19.76,19.70,19.01,18.43$.

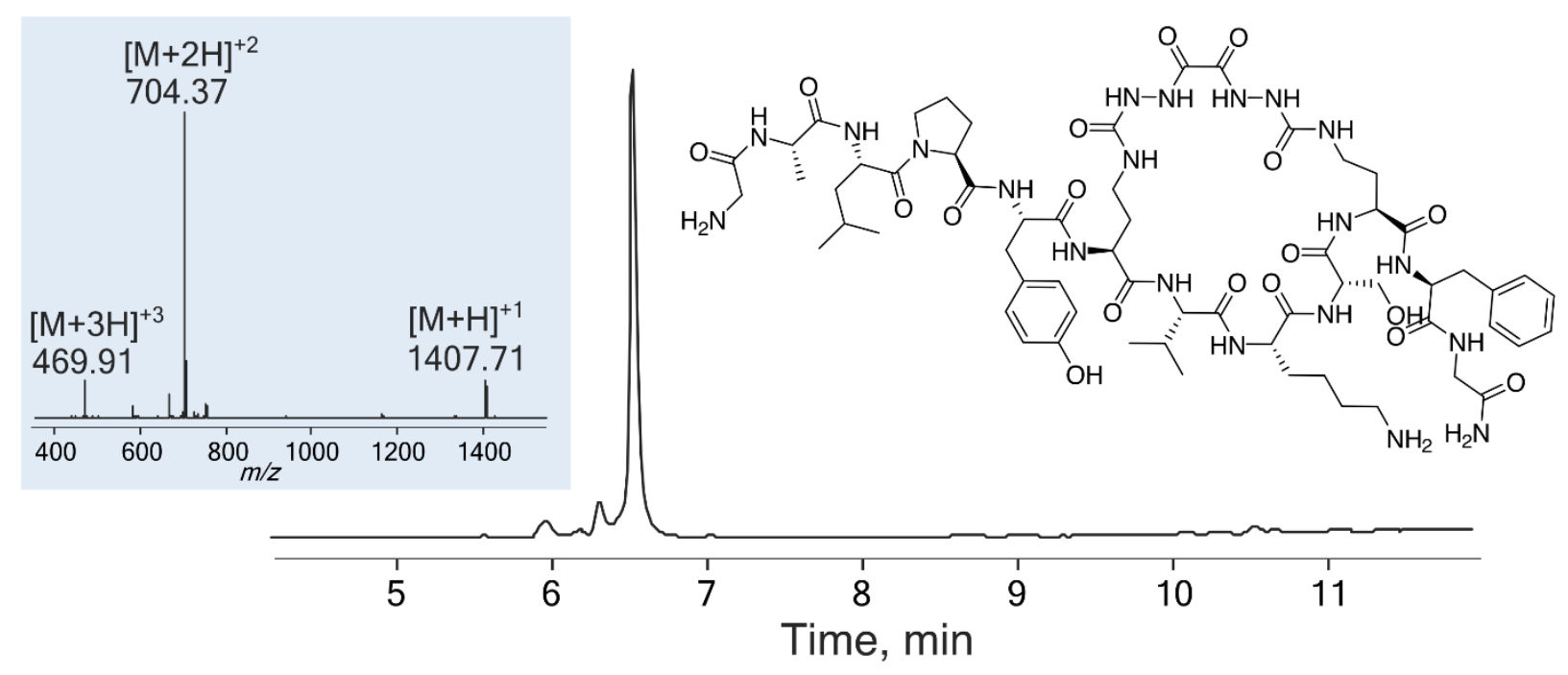

Figure S12. HPLC-MS (TIC) chromatogram for the purified cyclized peptide $\mathbf{1 b}$ with MS inset on the left and the peptide structure on the right. Calc. monoisotopic mass $=1406.71 \mathrm{Da}$.

\subsection{7. $\mathrm{H}_{2} \mathrm{~N}-\mathrm{Gly}-\mathrm{Ala}-\mathrm{Leu}-\mathrm{Pro}-\mathrm{Tyr}-\mathrm{Glu}\left(\mathrm{CONHNH}_{2}\right)$-Val-Lys-Ser-Glu$\left(\mathrm{CONHNH}_{2}\right)$-Phe-Gly-} $\mathrm{CONH}_{2}$ cyclized with succinic dihydrazide.

$41.36 \mathrm{mg}$ of peptide 1 were dissolved in $16.2 \mathrm{~mL}$ of oxidation buffer, oxidized with $1.62 \mathrm{~mL}$ of $200 \mathrm{mM}$ sodium nitrite, and cyclized with $369 \mathrm{~mL}$ of $5 \mathrm{mM}$ succinic dihydrazide as described in section $2.5 .11 .6 \mathrm{~g}$ citric acid monohydrate was added to the reaction mixture and excess acetonitrile was removed by rotary evaporation. The cyclized peptide $\mathbf{1 b}$ was purified with RP-HPLC, yielding $20.5 \mathrm{mg}$ of the desired peptide as a white powder after lyophilization. The peptide was isolated as a trifluoroacetic acid salt.

${ }^{1} \mathrm{H}$ NMR (600 MHz, DMSO-d $)^{\text {) }}: \delta 9.69$ (s, 1H), 9.66 (s, 1H), 8.50 (d, $\left.J=7.3 \mathrm{~Hz}, 1 \mathrm{H}\right), 8.22$ (d, $J=7.5$ $\mathrm{Hz}, 1 \mathrm{H}), 8.15-8.18(\mathrm{~m}, 1 \mathrm{H}), 8.06(\mathrm{~d}, J=8.3 \mathrm{~Hz}, 1 \mathrm{H}), 8.04(\mathrm{~d}, J=8.0 \mathrm{~Hz}, 1 \mathrm{H}), 7.99(\mathrm{~m}, 3 \mathrm{H}), 7.93(\mathrm{~s}, 1 \mathrm{H})$, $7.81-7.83(\mathrm{~m}, 1 \mathrm{H}), 7.72-7.79(\mathrm{~m}, 2 \mathrm{H}), 7.68(\mathrm{~m}, 2 \mathrm{H}), 7.23-7.28(\mathrm{~m}, 4 \mathrm{H}), 7.20(\mathrm{t}, J=6.2 \mathrm{~Hz}, 1 \mathrm{H}), 7.13$ (m, 1H), 7.09 (s, 1H), $7.05(\mathrm{~s}, 3 \mathrm{H}), 7.00(\mathrm{~d}, J=8.1 \mathrm{~Hz}, 2 \mathrm{H}), 6.61(\mathrm{~d}, J=8.3 \mathrm{~Hz}, 2 \mathrm{H}), 6.39(\mathrm{~s}, 1 \mathrm{H}), 4.47-$ $7.52(\mathrm{~m}, 1 \mathrm{H}), 4.43-7.46(\mathrm{~m}, 1 \mathrm{H}), 4.36-7.42(\mathrm{~m}, 2 \mathrm{H}), 4.28-7.34(\mathrm{~m}, 3 \mathrm{H}), 4.17-7.27(\mathrm{~m}, 2 \mathrm{H}), 4.12-$ $7.14(\mathrm{~m}, 1 \mathrm{H}), 3.68(\mathrm{dd}, J=16.7,5.8 \mathrm{~Hz}, 1 \mathrm{H}), 3.54-3.63(\mathrm{~m}, 6 \mathrm{H}), 3.45(\mathrm{~s}, 1 \mathrm{H}), 2.98-3.12(\mathrm{~m}, 4 \mathrm{H}), 2.96$ 
$(\mathrm{m}, 1 \mathrm{H}), 2.88(\mathrm{~d}, J=9.9 \mathrm{~Hz}, 1 \mathrm{H}), 2.81(\mathrm{dd}, J=13.2,10.8 \mathrm{~Hz}, 1 \mathrm{H}), 2.68-2.76(\mathrm{~m}, 3 \mathrm{H}), 2.41(\mathrm{~m}, 3 \mathrm{H}), 2.08$ $-2.15(\mathrm{~m}, 1 \mathrm{H}), 1.97(\mathrm{~s}, 1 \mathrm{H}), 1.84(\mathrm{~m}, 3 \mathrm{H}), 1.74-1.81(\mathrm{~m}, 2 \mathrm{H}), 1.66-1.71(\mathrm{~m}, 2 \mathrm{H}), 1.58-1.65(\mathrm{~m}, 2 \mathrm{H})$, $1.48-1.56(\mathrm{~m}, 4 \mathrm{H}), 1.46(\mathrm{~m}, 1 \mathrm{H}), 1.35-1.39(\mathrm{~m}, 1 \mathrm{H}), 1.28-1.33(\mathrm{~m}, 2 \mathrm{H}), 1.20(\mathrm{~d}, J=7.0 \mathrm{~Hz}, 3 \mathrm{H}), 0.85$ $-0.91(\mathrm{~m}, 12 \mathrm{H})$.

${ }^{13} \mathrm{C}$ NMR (150 MHz, DMSO- $\left.d_{6}\right): \delta$ 172.62, 172.53, 172.25, 172.13, 172.03, 171.94, 171.82, 171.70, $171.55,171.49,171.37,171.24,170.76,165.60,159.04,158.90,158.87,156.05,137.98,130.58,129.58$, $128.61,127.91,126.85,117.52,115.26,61.32,59.98,59.26,55.77,54.79,54.57,53.03,51.49,51.19,49.33$, 48.46, 47.14, 42.29, 40.31, 38.96, 37.51, 36.68, 36.58, 32.91, 32.13, 31.41, 30.06, 29.14, 29.58, 26.76, $26.71,24.82,24.54,23.58,22.27,21.81,19.69,18.74,18.32$.

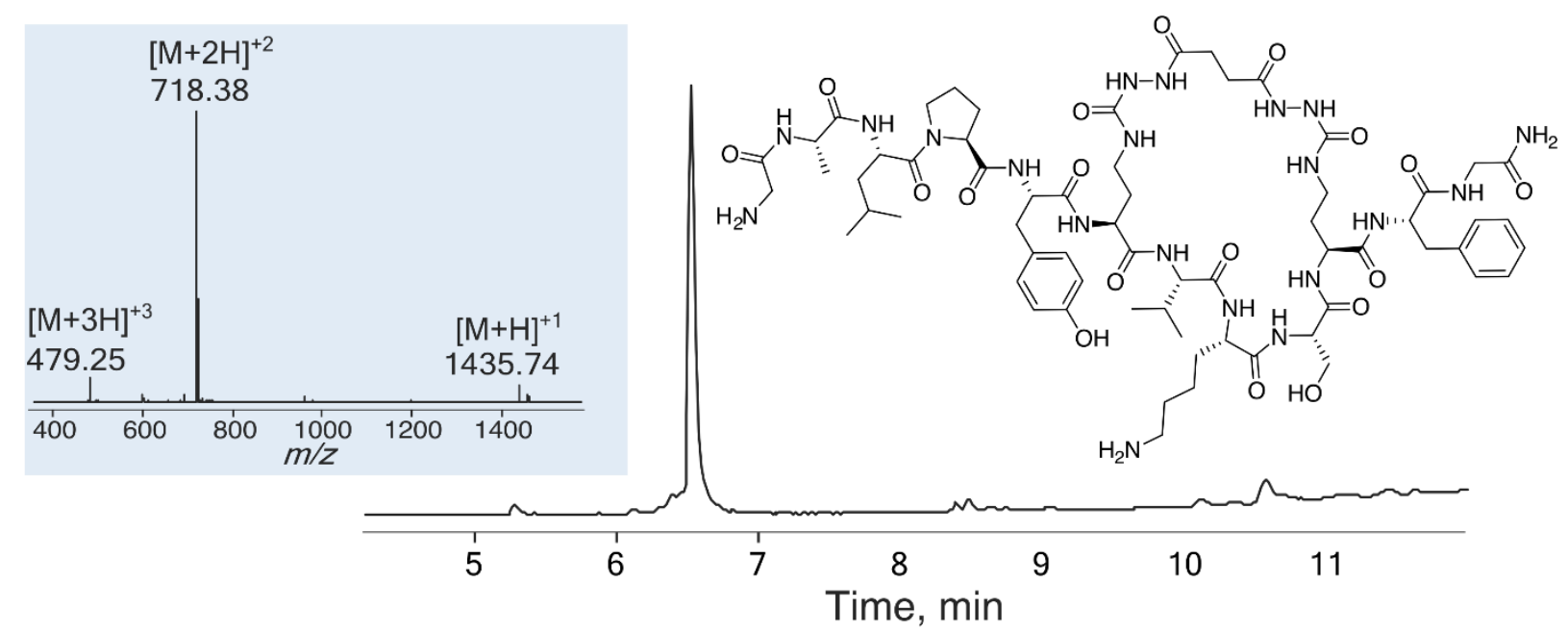

Figure S13. HPLC-MS (TIC) chromatogram for the purified cyclized peptide 1c with MS inset on the left and the peptide structure on the right. Calc. monoisotopic mass $=1434.74 \mathrm{Da}$.

\subsection{8. $\mathrm{H}_{2} \mathrm{~N}-\mathrm{Gly}$-Ala-Leu-Pro-Tyr-Glu(CONHNH$\left.{ }_{2}\right)$-Val-Lys-Ser-Glu(CONHNH$\left.{ }_{2}\right)$-Phe-Gly-}

$\mathrm{CONH}_{2}$ cyclized with adipic acid dihydrazide.

$44.53 \mathrm{mg}$ of peptide 1 were dissolved in $11.0 \mathrm{~mL}$ of oxidation buffer, oxidized with $1.1 \mathrm{~mL}$ of $200 \mathrm{mM}$ sodium nitrite, and cyclized with $400 \mathrm{~mL}$ of $5 \mathrm{mM}$ adipic acid dihydrazide as described in section 2.5. 12.5 g citric acid monohydrate was added to the reaction mixture and excess acetonitrile was removed by rotary evaporation. The cyclized peptide was purified by RP-HPLC, yielding $15.5 \mathrm{mg}$ of the desired peptide after lyophilization as white powder. The peptide was isolated as a trifluoroacetic acid salt.

${ }^{1} \mathrm{H}$ NMR $\left(600 \mathrm{MHz}, \mathrm{DMSO}-d_{6}\right): \delta 9.53(\mathrm{~s}, 1 \mathrm{H}), 9.49(\mathrm{~s}, 1 \mathrm{H}), 8.51(\mathrm{~d}, J=7.2 \mathrm{~Hz}, 1 \mathrm{H}), 8.20$ (d, $J=7.2$ $\mathrm{Hz}, 1 \mathrm{H}), 8.15(\mathrm{~s}, 1 \mathrm{H}), 8.01-8.10(\mathrm{~m}, 5 \mathrm{H}), 7.96(\mathrm{~m}, 1 \mathrm{H}), 7.92(\mathrm{~s}, 1 \mathrm{H}), 7.84(\mathrm{~s}, 1 \mathrm{H}), 7.73-7.81(\mathrm{~m}, 4 \mathrm{H})$, $7.23-7.27(\mathrm{~m}, 4 \mathrm{H}), 7.17-7.23(\mathrm{~m}, 3 \mathrm{H}), 7.14(\mathrm{~s}, 1 \mathrm{H}), 7.09(\mathrm{~s}, 1 \mathrm{H}), 6.99(\mathrm{~d}, J=7.9 \mathrm{~Hz}, 2 \mathrm{H}), 6.63(\mathrm{~d}, J=$ $7.9 \mathrm{~Hz}, 2 \mathrm{H}), 6.46(\mathrm{~s}, 1 \mathrm{H}), 6.37(\mathrm{~s}, 1 \mathrm{H}), 4.49(\mathrm{~m}, 1 \mathrm{H}), 4.43-4.47(\mathrm{~m}, 1 \mathrm{H}), 4.36-4.41(\mathrm{~m}, 2 \mathrm{H}), 4.25-4.35$ 
$(\mathrm{m}, 4 \mathrm{H}), 4.18-4.23(\mathrm{~m}, 1 \mathrm{H}), 4.15(\mathrm{t}, J=6.6 \mathrm{~Hz}, 1 \mathrm{H}), 3.69(\mathrm{dd}, J=16.6,5.4 \mathrm{~Hz}, 1 \mathrm{H}), 3.52-3.64(\mathrm{~m}, 6 \mathrm{H})$, $3.45(\mathrm{~s}, 1 \mathrm{H}), 2.96-3.14(\mathrm{~m}, 4 \mathrm{H}), 2.94(\mathrm{~m}, 1 \mathrm{H}), 2.88(\mathrm{~d}, J=10.7 \mathrm{~Hz}, 1 \mathrm{H}), 2.79-2.84(\mathrm{~m}, 1 \mathrm{H}), 2.67-2.83$ (m, 3H), $2.12(\mathrm{~m}, 4 \mathrm{H}), 2.03-2.08(\mathrm{~m}, 1 \mathrm{H}), 1.97(\mathrm{~s}, 1 \mathrm{H}), 1.83(\mathrm{~m}, 3 \mathrm{H}), 1.70-1.77(\mathrm{~m}, 2 \mathrm{H}), 1.58-1.68$ $(\mathrm{m}, 2 \mathrm{H}), 1.48-1.57(\mathrm{~m}, 8 \mathrm{H}), 1.41-1.46(\mathrm{~m}, 1 \mathrm{H}), 1.37(\mathrm{~d}, J=9.8 \mathrm{~Hz}, 1 \mathrm{H}), 1.28-1.35(\mathrm{~m}, 2 \mathrm{H}), 1.20(\mathrm{~d}, J$ $=6.8 \mathrm{~Hz}, 3 \mathrm{H}), 0.85-0.92(\mathrm{~m}, 12 \mathrm{H})$.

${ }^{13} \mathrm{C}$ NMR (150 MHz, DMSO-d $): \delta 172.85,172.80,172.01,171.87,171.75,171.69171 .63,171.61$, 171.51, 171.33, 171.27, 171.07, 170.67, 165.81, 158.80 (d, $J=23.1 \mathrm{~Hz}), 158.82,156.26,138.12,130.58$, 129.61, 128.56, 127.94, 126.77, 117.44 (q, $J=303 \mathrm{~Hz}), 115.29,61.91,59.90,58.73,55.40,54.80,54.55$, $52.91,51.48,51.06,49.28,48.51,47.11,42.47,40.60,39.24,37.67,36.85,36.59,33.50,33.15,33.08$, $32.67,31.50,30.32,29.18,26.93,24.83,24.54,23.63,22.34,21.89,19.76,19.00,18.42$.

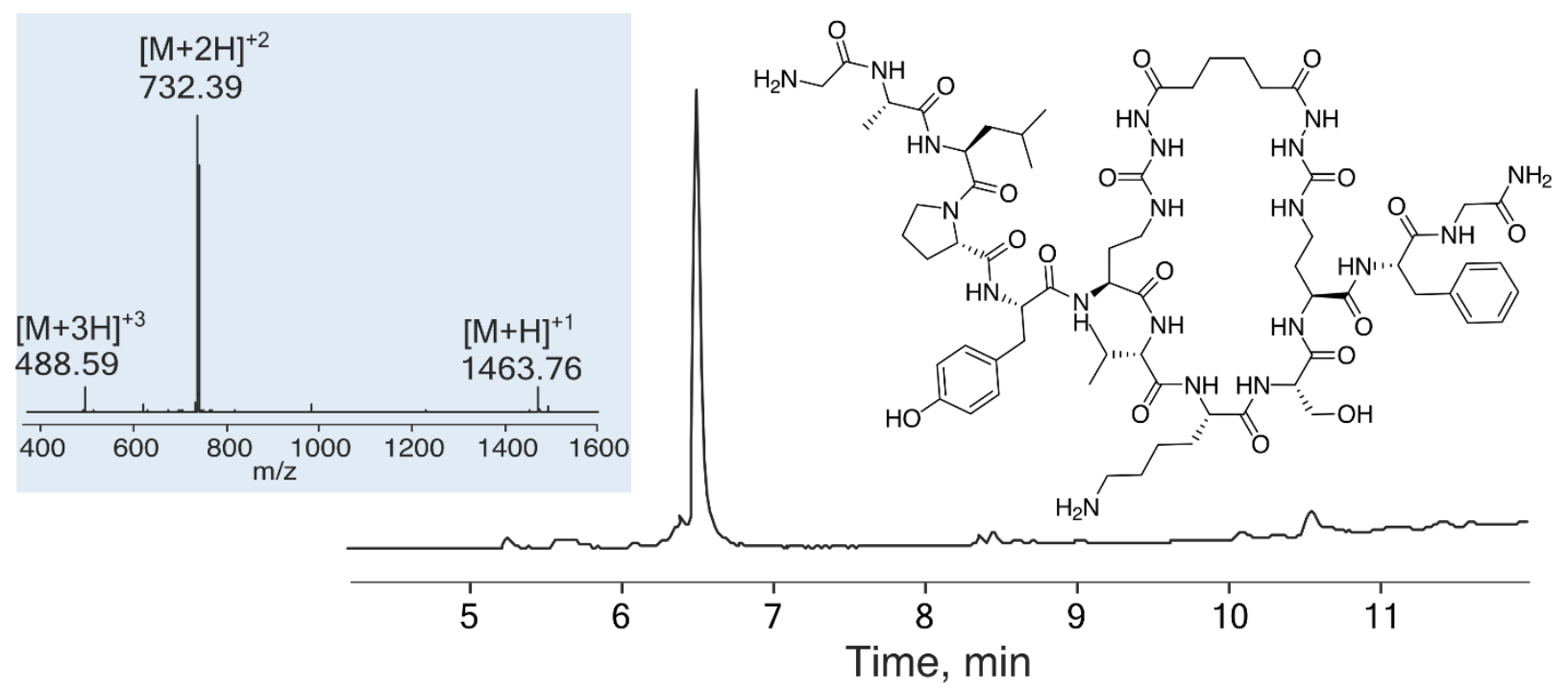

Figure S14. HPLC-MS (TIC) chromatogram for the purified cyclized peptide 1d with MS inset on the left and the peptide structure on the right. Calc. monoisotopic mass $=1462.76 \mathrm{Da}$.

\subsection{Macrocyclization of acyl azides}

To test whether it is possible cyclize peptide acyl azides directly with dicarboxylic acid hydrazides circumventing Curtius rearrangement we performed several reactions. Dihydrazide 1 was oxidized with sodium nitrite essentially as described in section 2.6 to yield a peptide bearing two acyl azide moieties. Since acyl azides are much less reactive than isocyanates, we co-incubated the reaction partners at higher concentrations trying to mimic established protocols for acyl azides conjugation (Fang, Li et al. Angew. Chem. Int. Ed. 2011, 50, 7645-7649). Namely, we performed five experiments:

1. $1.5 \mathrm{mM}$ peptide $+50 \mathrm{mM}$ succinic dihydrazide in $50 \% \mathrm{~A} / 50 \% \mathrm{~B}$ at $\mathrm{rt}$

2. $1.0 \mathrm{mM}$ peptide $+50 \mathrm{mM}$ succinic dihydrazide in $50 \% \mathrm{~A} / 50 \% \mathrm{~B}$ at $\mathrm{rt}$ 
3. $1.0 \mathrm{mM}$ peptide $+5 \mathrm{mM}$ succinic dihydrazide in $50 \% \mathrm{~A} / 50 \% \mathrm{~B}$ at $\mathrm{rt}$

4. $1.5 \mathrm{mM}$ peptide $+50 \mathrm{mM}$ succinic dihydrazide in $50 \% \mathrm{~A} / 50 \% \mathrm{~B}$ at $60{ }^{\circ} \mathrm{C}$

5. $1.0 \mathrm{mM}$ peptide $+50 \mathrm{mM}$ succinic dihydrazide in $50 \% \mathrm{~A} / 50 \% \mathrm{~B}$ at $60{ }^{\circ} \mathrm{C}$

In all cases we observed a complex, virtually inseparable mixture of products, and did not detect the expected cyclic product by HPLC/MS. A representative LCMS chromatogram, which was obtained for the reaction \#4 is illustrated in the Fig. S15.

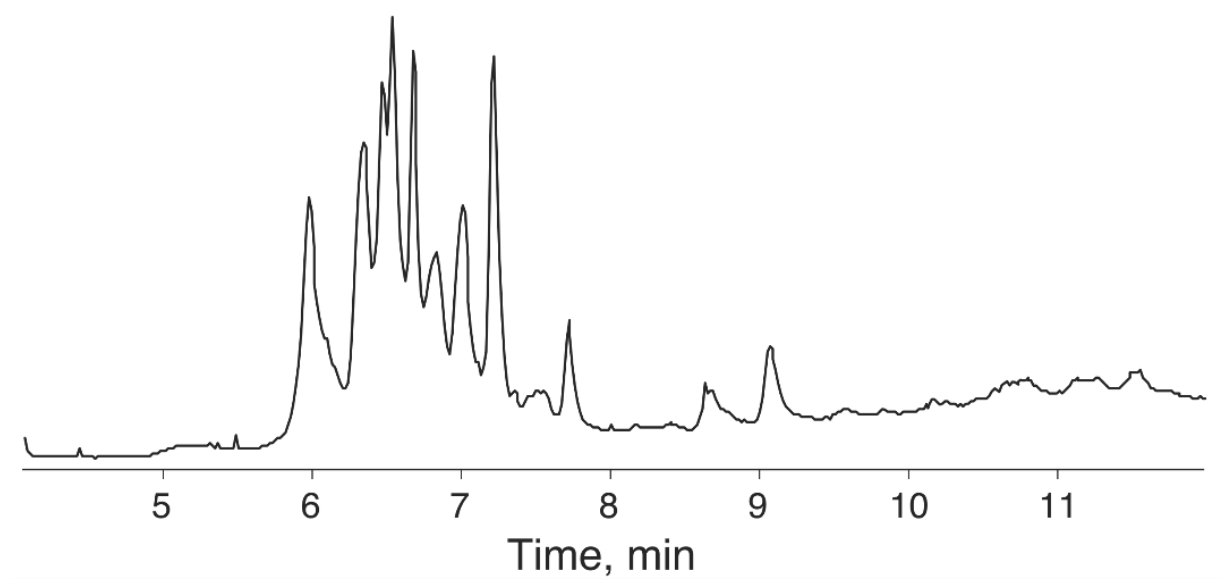

Figure S15. HPLC-MS (TIC) chromatogram of the crude reaction mixture between double acyl azide of peptide $\mathbf{1}$ and succinic dihydrazide. None of the major products correspond to the expected cyclized peptide.

\subsection{Chemical stability of macrocyclized peptides}

Chemical stability of macrocyclized peptides was studied on constructs $\mathbf{1 b}$ and $\mathbf{1 c}$. The peptides were stapled as described in section 2.5. Crude reaction mixture were diluted fiftyfold with one of the following solutions:

1. Water with $1 \%$ TFA pHed to 2.0;

2. Water with $\mathrm{x} \mathrm{mM} \mathrm{NaOH}$ pHed to 9.5;

3. $50 \mathrm{mM}$ Tris buffer containing $50 \mathrm{mM}$ TCEP, $\mathrm{pH} 7.0$;

4. $50 \mathrm{mM}$ Tris buffer containing $50 \mathrm{mM}$ DTT, $\mathrm{pH} 7.0$;

5. $50 \mathrm{mM}$ Tris buffer containing $50 \mathrm{mM} \mathrm{NaNO}_{2}, \mathrm{pH} 7.3$;

The mixtures were incubated at room temperature for $24 \mathrm{~h}$ and then subject to HPLC-MS analysis. The chromatograms were automatically integrated in Mass Hunter and relative peak areas were compared between the experiments to determine the extent of the peptide degradation. In all cases we observed insignificant $(<2 \%$ of the total peak area) changes in the abundance of the peptide of interest in the reaction mixture, and thus, concluded that no degradation of the cyclized material happened within a 24 hour timeframe. 


\subsection{Proteolytic stability of macrocyclized peptides}

$200 \mu \mathrm{g} / \mathrm{mL}$ solutions of peptides $\mathbf{1}$, 1a-d were incubated in digesting buffer $(50 \mathrm{mM}$ Tris, $100 \mathrm{mM} \mathrm{NaCl}$, $5 \mathrm{mM} \mathrm{CaCl}_{2}$ buffer, $\mathrm{pH}$ 7.4) for 30 minutes. Then, $1 \mathrm{mg} / \mathrm{mL}$ stock solutions of trypsin and proteinase $\mathrm{K}$ in the same buffer were added to peptides to a final concentration of $200 \mathrm{ng} / \mathrm{mL}$ for trypsin and $40 \mathrm{ng} / \mathrm{mL}$ for proteinase $\mathrm{K}(1000: 1(\mathrm{w} / \mathrm{w})$ ratio of substrate to protease ratio for trypsin, and 5000: $1(\mathrm{w} / \mathrm{w})$ for proteinase $\mathrm{K})$. The digests were performed at $37{ }^{\circ} \mathrm{C}$ for one hour, and three intermediate time points were taken at 5 , 13 and 30 minutes. The reactions were quenched by adding excess $50 \%$ A/50\% B and analyzed by HPLCMS as described in section 2.6. To quantitate the extent of proteolysis, chromatograms were manually integrated and the percentage of intact peptide was plotted as a function of time. As shown in Fig. S16, all stapled peptides clearly demonstrated improved stability to both trypsin and proteinase $\mathrm{K}$ as compared to the unstapled control 1.
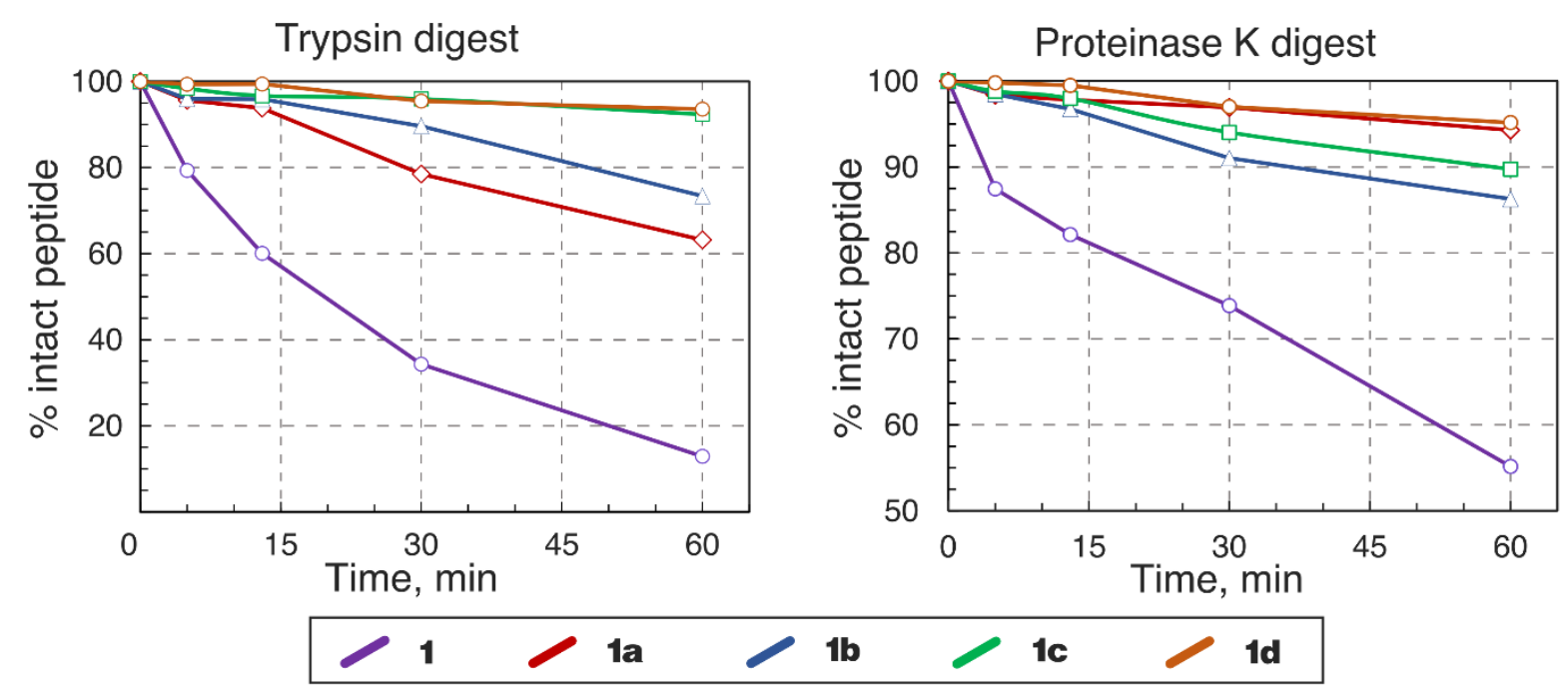

Figure S16. Comparative proteolytic degradation of peptides $\mathbf{1}$ and 1a-d with trypsin and proteinase K.

\subsection{Bilayer interferometry data analysis}

Binding data collected for peptides 1, 1a-d according to the procedure described in section 2.9 were processed as follows. Reference readings were subtracted universally from both association and dissociation curves. Association curves were aligned to the last five seconds of the base line, and dissociation curves were aligned to the last value of association curves. No curve-smoothing filtering was performed. The resulting curves were fit to the following equations:

$$
\text { For association: } \quad \text { response }=R_{\max } \frac{1}{1+\frac{k_{d}}{k_{a}[C C A]}}\left(1-e^{-\left(k_{a}[C C A]+k_{d}\right) t}\right)
$$


where $R_{\max }$ is a fitting parameter, $k_{a}$ and $k_{d}$ are association and dissociation constants respectively, [CCA] is the concentration of C-CA protein, and $t$ is aligned time.

$$
\text { For dissociation: } \text { response }=R_{0} e^{-k_{d} t^{\prime}}
$$

where $R_{0}$ is the last response value obtained from the first equation, $t$ ' is aligned time for the dissociation step. A BFGS Quasi-Newton minimization algorithm on MATLAB (fminunc) was used to find parameters $k_{d}, k_{a}$, and $R_{\max }$ that minimized the squared difference between calculated and observed responses during association and dissociation. Binding constant, $K_{D}$, was calculated from the fitting parameters $k_{a}$ and $k_{d}$ as the ratio of the two. Reported $K_{D}$ values are average of five measurements and reported errors are standard deviations from these values. Figures S17-S21 show sensograms and fitting for each tested construct.

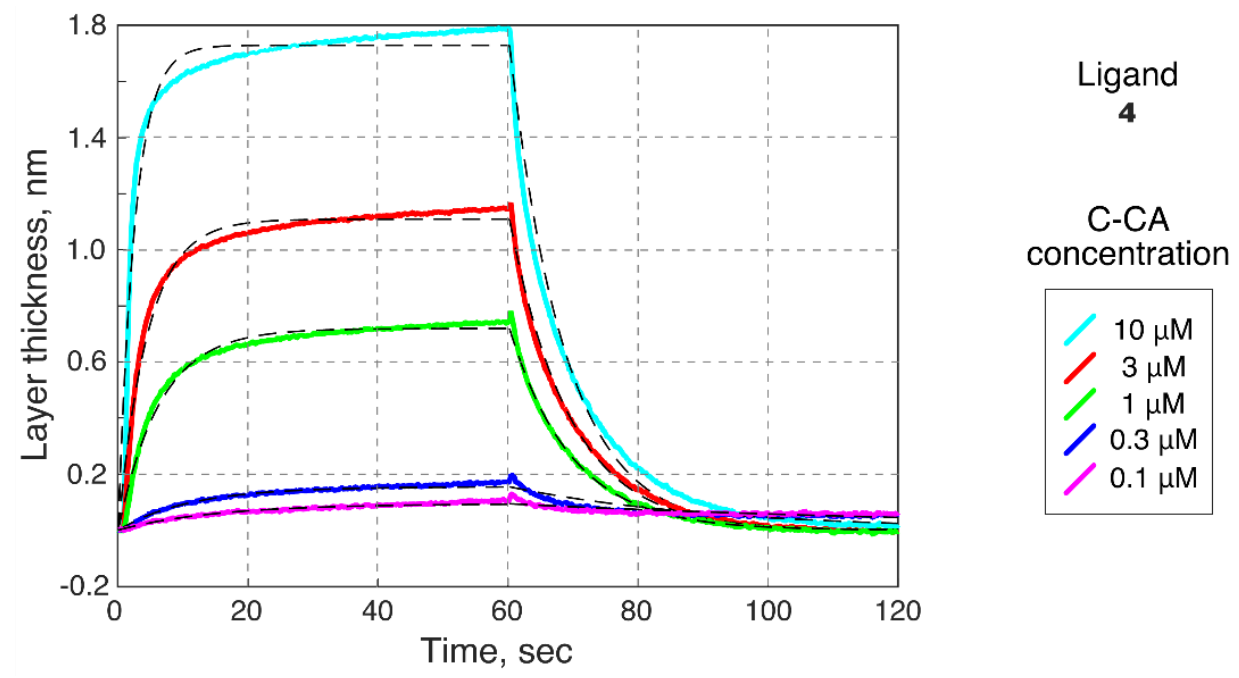

Figure S17. Binding kinetics between peptide 4 and C-CA as measured by bilayer interferometry. Tip-bound peptide was associated with five different concentrations of protein. Best fits for each curve are shown as dotted lines.
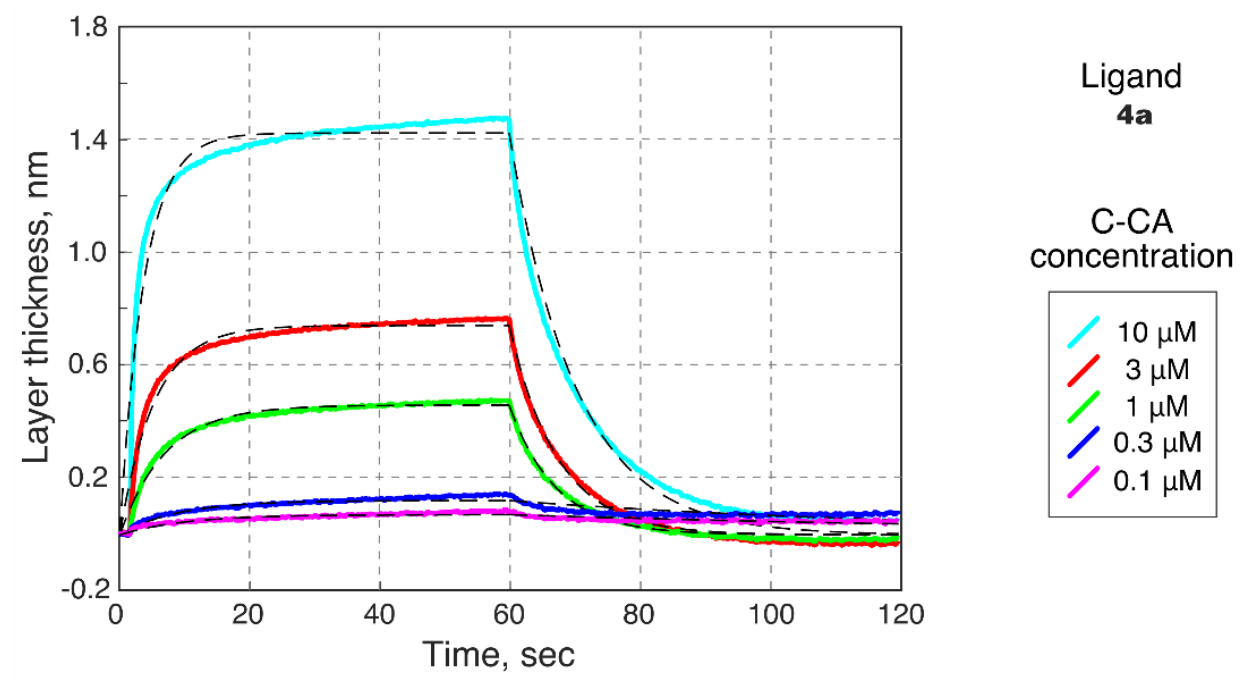

Figure S18. Binding kinetics between peptide $\mathbf{4 a}$ and C-CA as measured by bilayer interferometry. Tip-bound peptide was associated with five different concentrations of protein. Best fits for each curve are shown as dotted lines. 


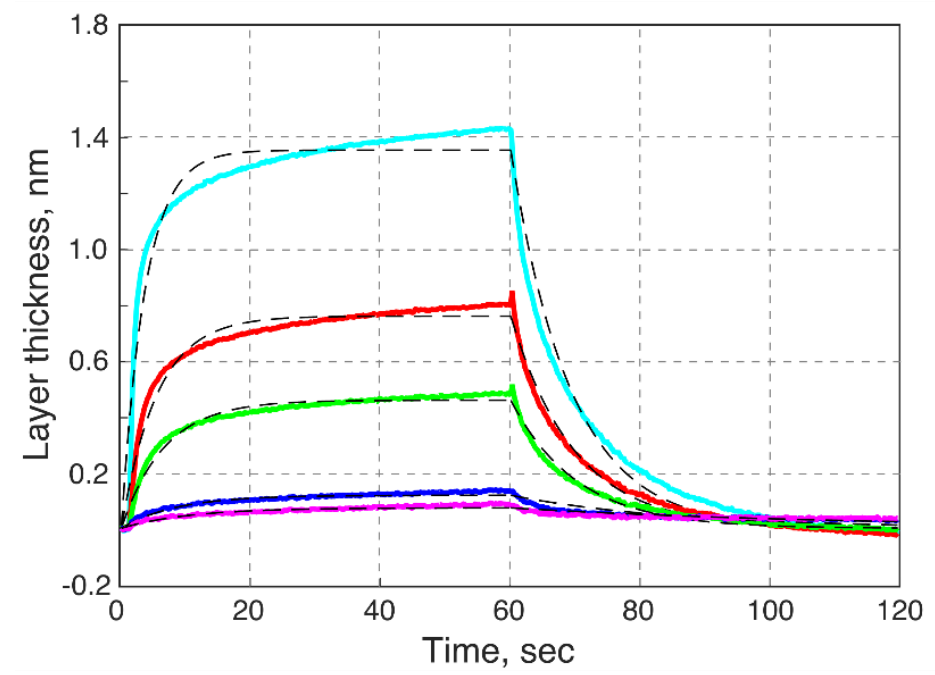

\section{Ligand \\ 4b \\ C-CA concentration}

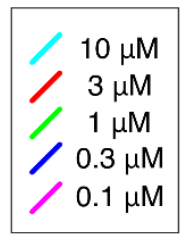

Figure S19. Binding kinetics between peptide $\mathbf{4 b}$ and C-CA as measured by bilayer interferometry. Tip-bound peptide was associated with five different concentrations of protein. Best fits for each curve are shown as dotted lines.
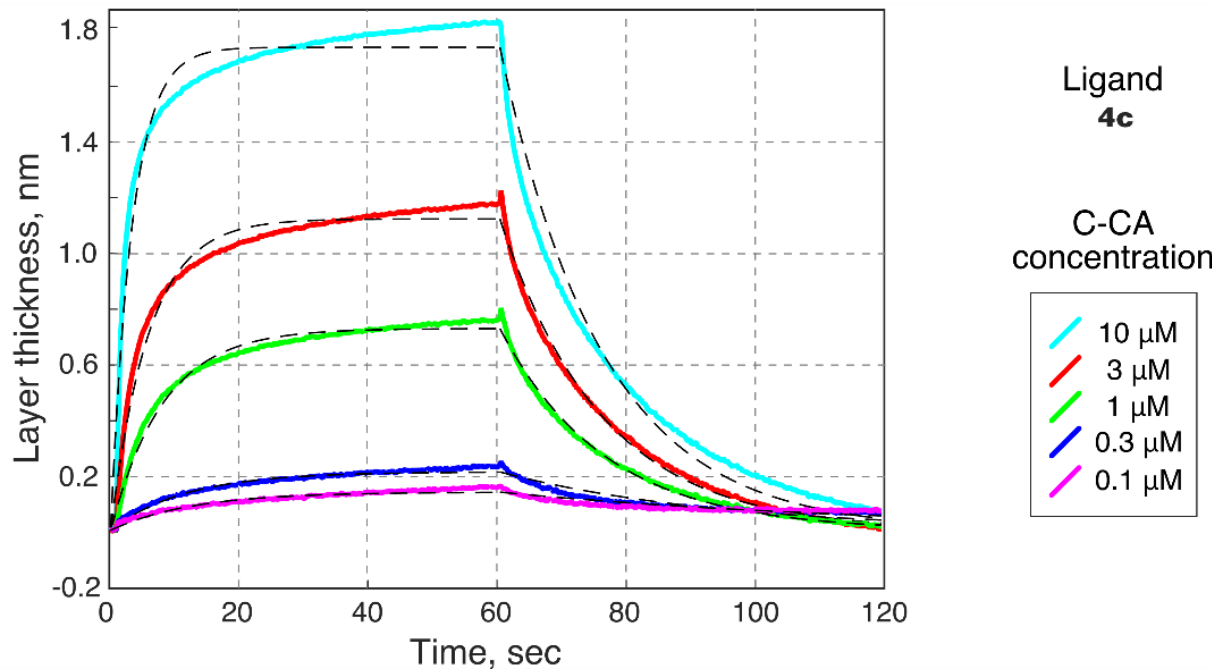

Figure S20. Binding kinetics between peptide $4 \mathbf{c}$ and C-CA as measured by bilayer interferometry. Tip-bound peptide was associated with five different concentrations of protein. Best fits for each curve are shown as dotted lines. 

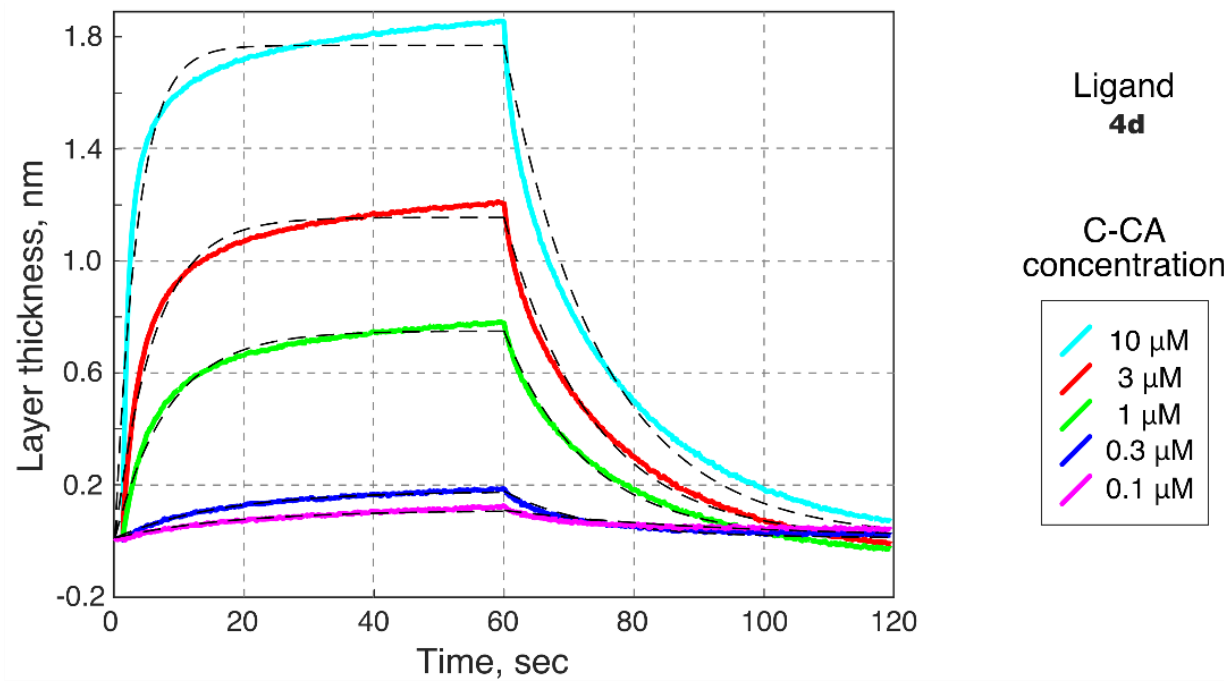

Figure S21. Binding kinetics between peptide 4d and C-CA as measured by bilayer interferometry. Tip-bound peptide was associated with five different concentrations of protein. Best fits for each curve are shown as dotted lines. 


\subsection{NMR Spectra}

\section{Peptide 1}

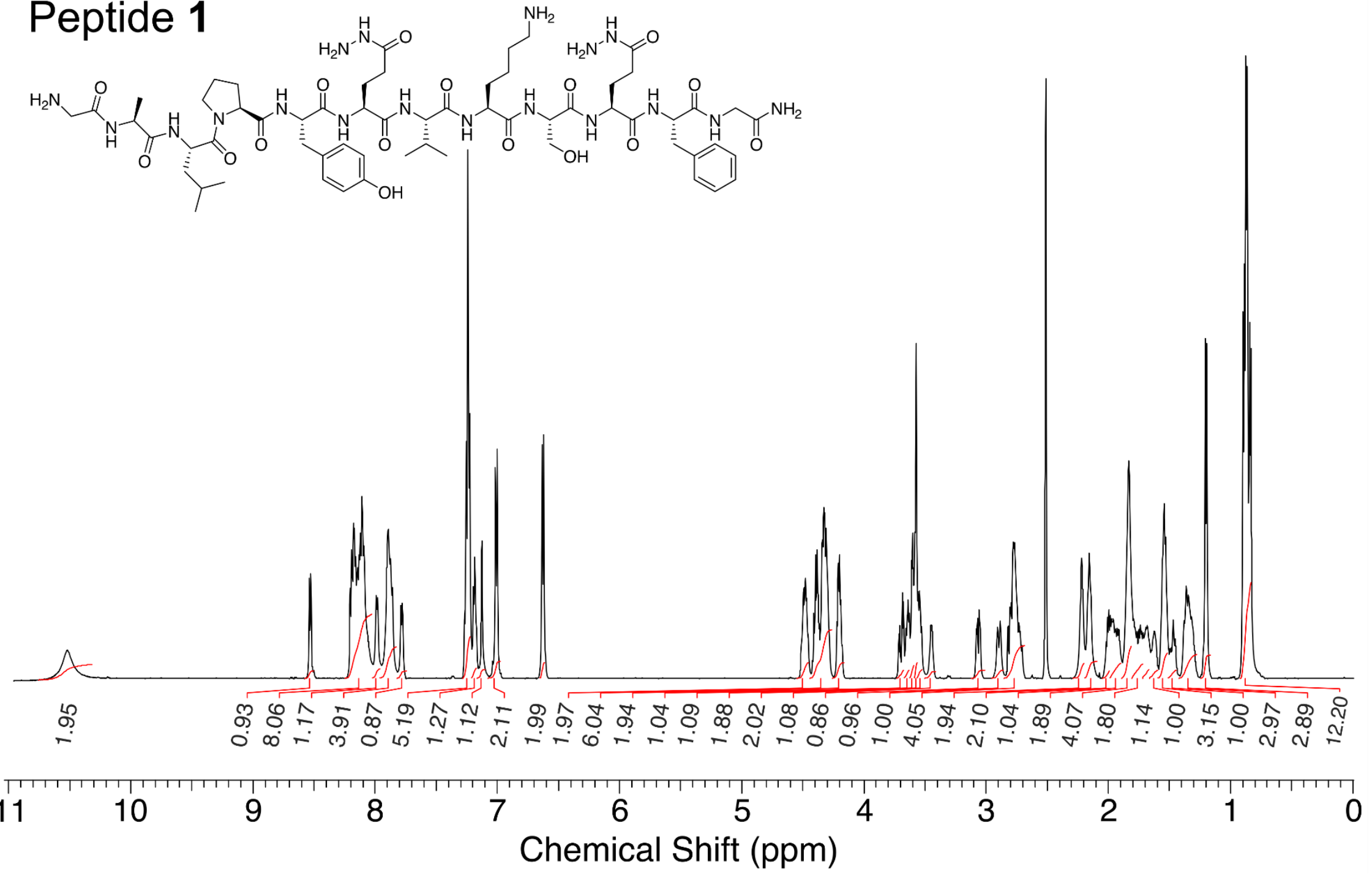

Figure S22. ${ }^{1} \mathrm{H}$ NMR (600 MHz, DMSO-d6) spectrum of peptide $\mathrm{H}_{2} \mathrm{~N}-\mathrm{GALPYE}\left(\mathrm{CONHNH}_{2}\right) \mathrm{VKSE}(\mathrm{CONHNH}) \mathrm{FG}_{2} \mathrm{CONH}_{2}($ peptide 1). 


\section{Peptide 1}
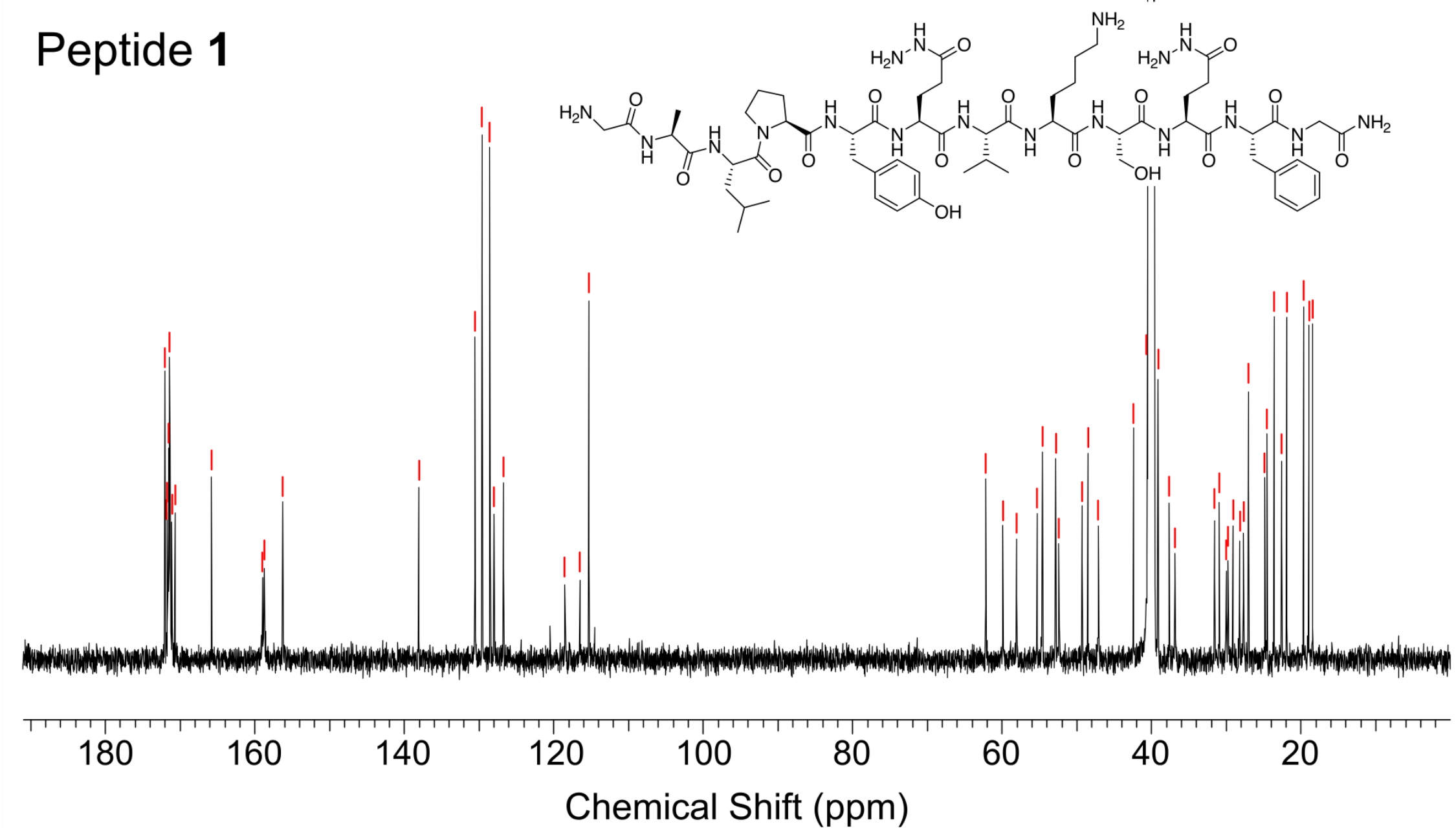

Figure S23. ${ }^{13} \mathrm{C}$ NMR (150 MHz, DMSO-d6) spectrum of peptide $\mathrm{H}_{2} \mathrm{~N}-\mathrm{GALPYE}(\mathrm{CONHNH}) \mathrm{VKSE}(\mathrm{CONHNH}) \mathrm{FG}-\mathrm{CONH} 2($ peptide 1). 
$\infty$

으으

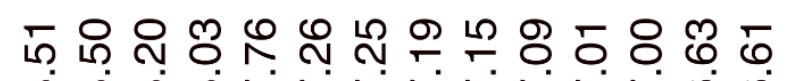

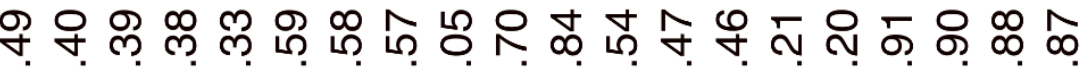

$\infty \infty \infty \infty \wedge \wedge \wedge \wedge$

\section{Peptide 1a}

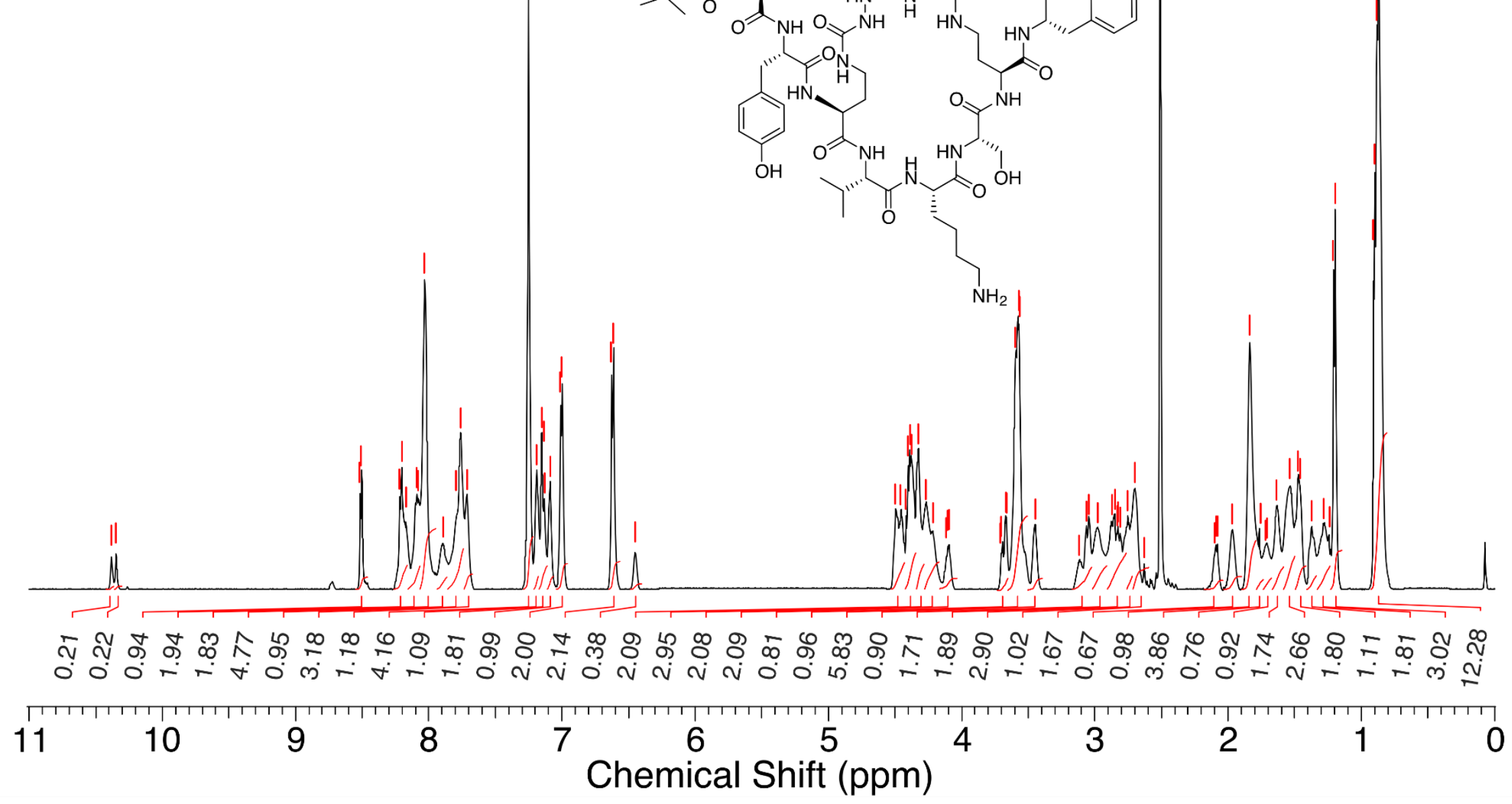

Figure S24. ${ }^{1} \mathrm{H}$ NMR (600 MHz, DMSO-d6) spectrum of peptide $\mathrm{H}_{2} \mathrm{~N}-\mathrm{GALPYE}(\mathrm{CONHNH})$ VKSE(CONHNH 2$)$ FG-CONH 2 cyclized with carbohydrazide (peptide 1a). 
-

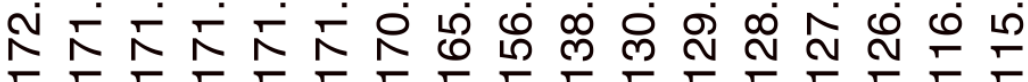

ని $\infty$ న

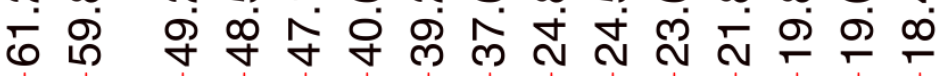

\section{Peptide 1a}

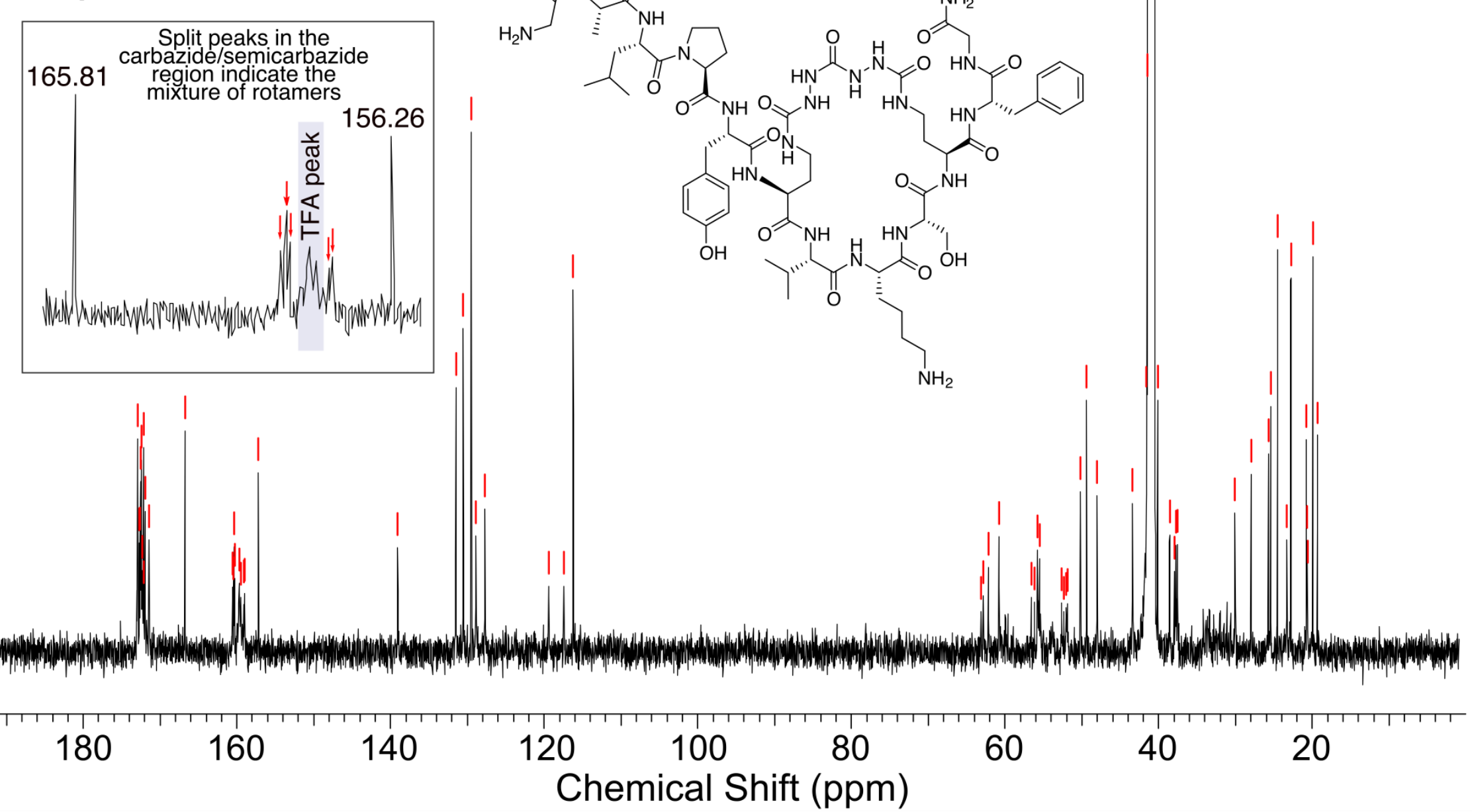

Figure S25. ${ }^{13} \mathrm{C}$ NMR (150 MHz, DMSO-d6) spectrum of peptide $\mathrm{H}_{2} \mathrm{~N}-\mathrm{GALPYE}(\mathrm{CONHNH} 2) \mathrm{VKSE}(\mathrm{CONHNH}) \mathrm{FG}_{2} \mathrm{CONH}_{2}$ cyclized with carbohydrazide (peptide 1a). 
œ ले

응 음

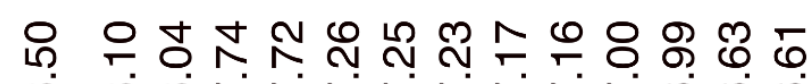

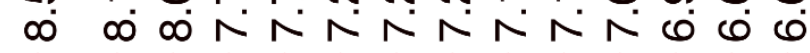

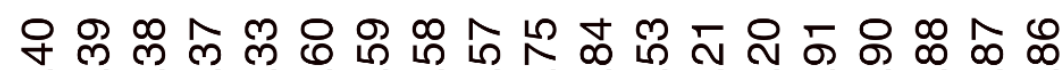

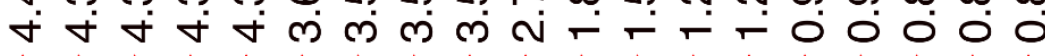

\section{Peptide 1b}

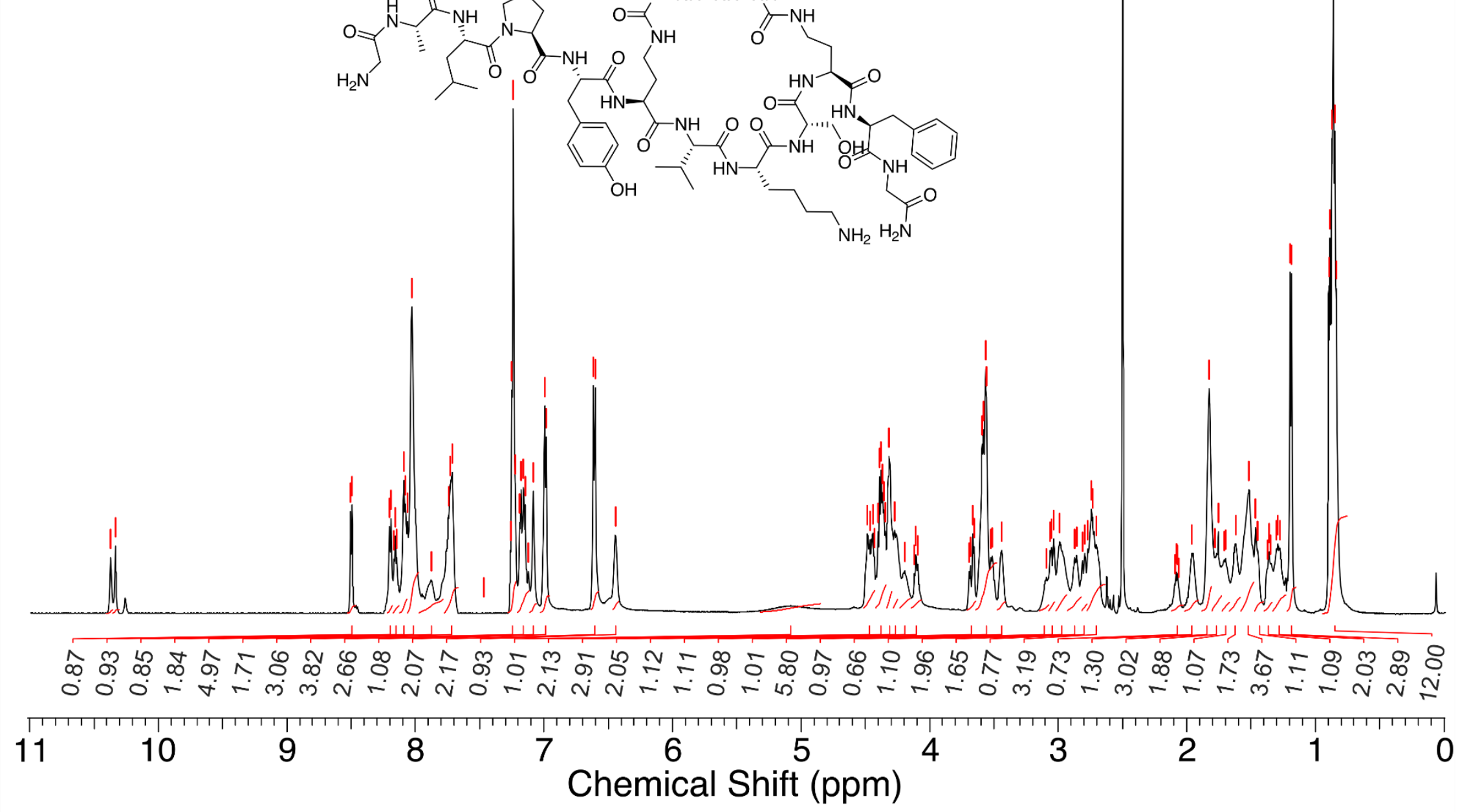

Figure S26. ${ }^{1} \mathrm{H}$ NMR (600 MHz, DMSO-d6) spectrum of peptide $\mathrm{H}_{2} \mathrm{~N}-\mathrm{GALPYE}(\mathrm{CONHNH})$ VKSE(CONHNH$)$ FG-CONH 2 cyclized with oxalyl dihydrazide (peptide 1b). 
б

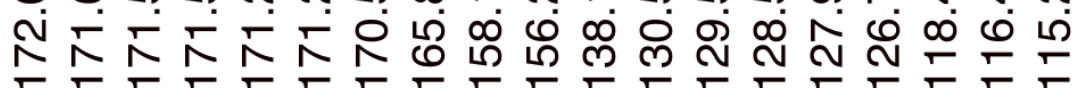

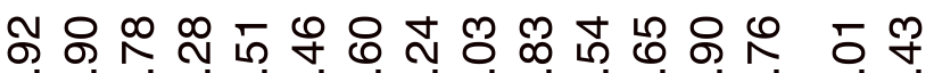

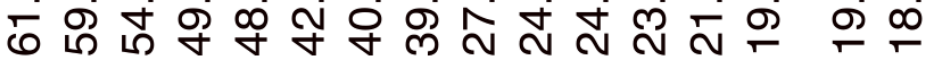

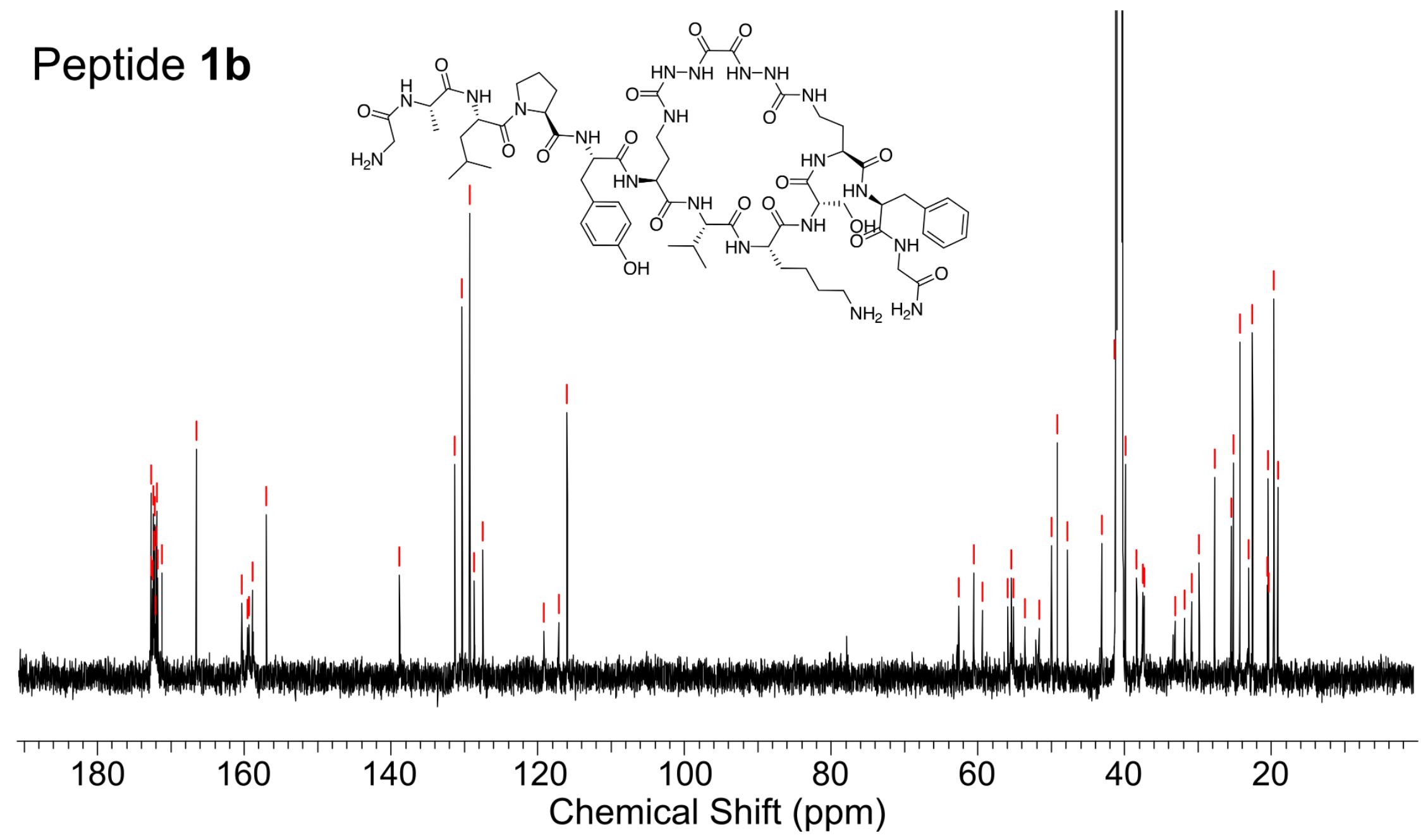

Figure S27. ${ }^{13} \mathrm{C}$ NMR $\left(150 \mathrm{MHz}\right.$, DMSO-d6) spectrum of peptide $\mathrm{H}_{2} \mathrm{~N}-\mathrm{GALPYE}\left(\mathrm{CONHNH}_{2}\right) \mathrm{VKSE}\left(\mathrm{CONHNH}_{2}\right) \mathrm{FG}-\mathrm{CONH}_{2}$ cyclized with oxalyl dihydrazide (peptide 1b). 


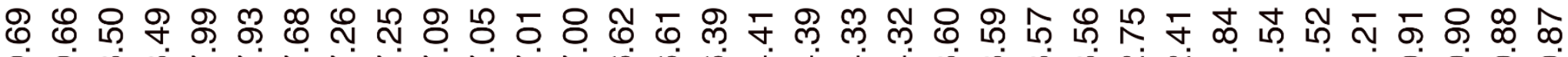
の

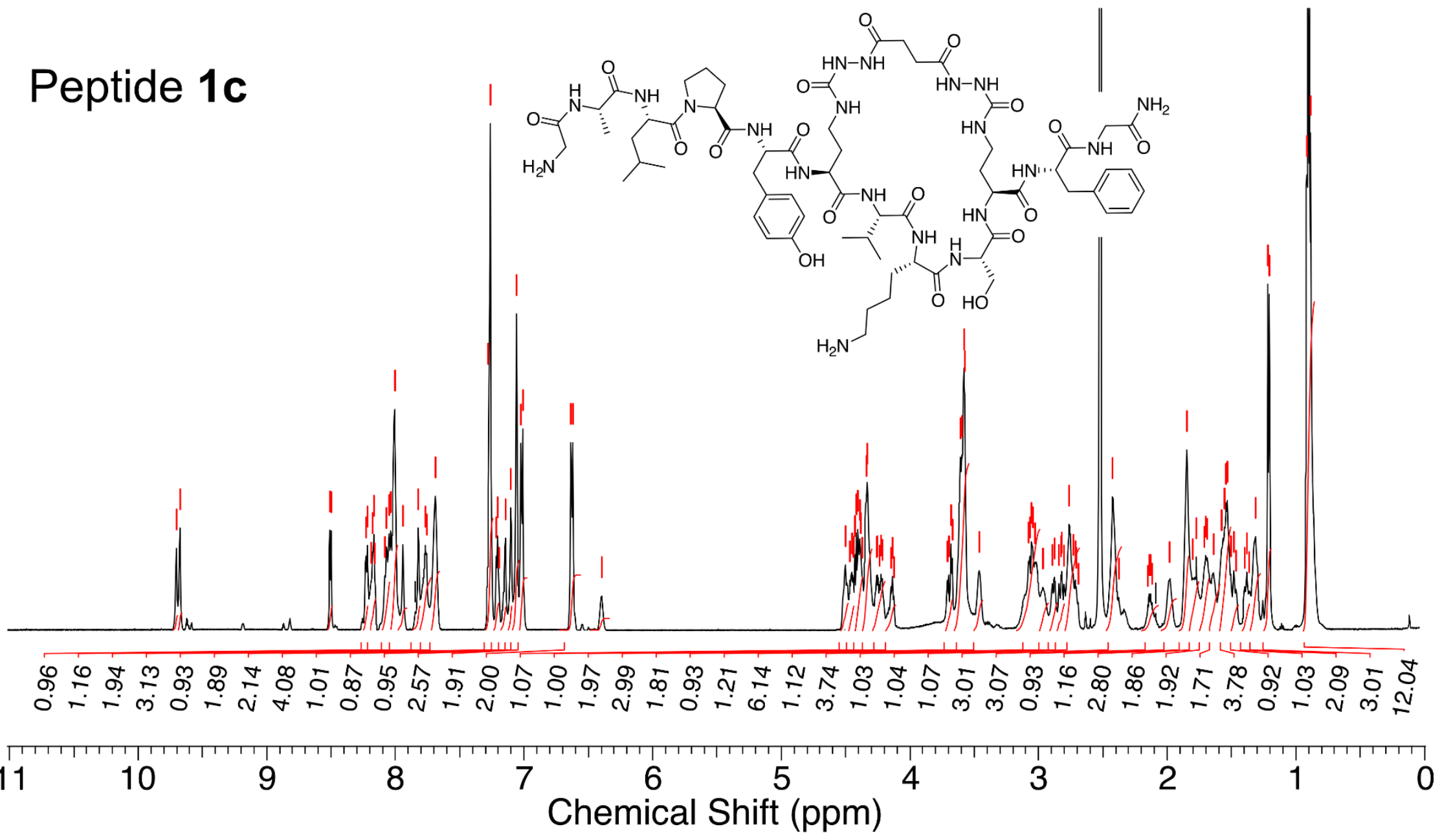

Figure S28. ${ }^{1} \mathrm{H}$ NMR (600 MHz, DMSO-d6) spectrum of peptide $\mathrm{H}_{2} \mathrm{~N}-\mathrm{GALPYE}(\mathrm{CONHNH} 2) \mathrm{VKSE}(\mathrm{CONHNH}) \mathrm{FG}_{2} \mathrm{CONH}_{2}$ cyclized with succinic acid dihydrazide (peptide 1c). 


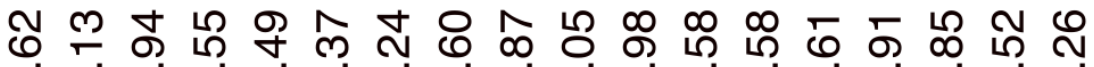

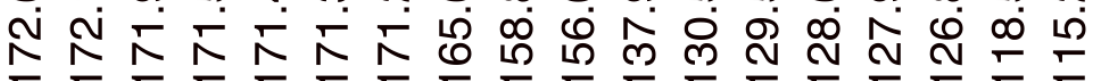

の

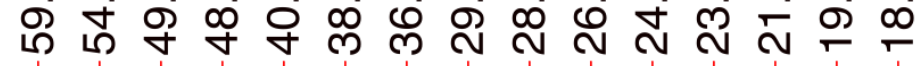

\section{Peptide 1c}

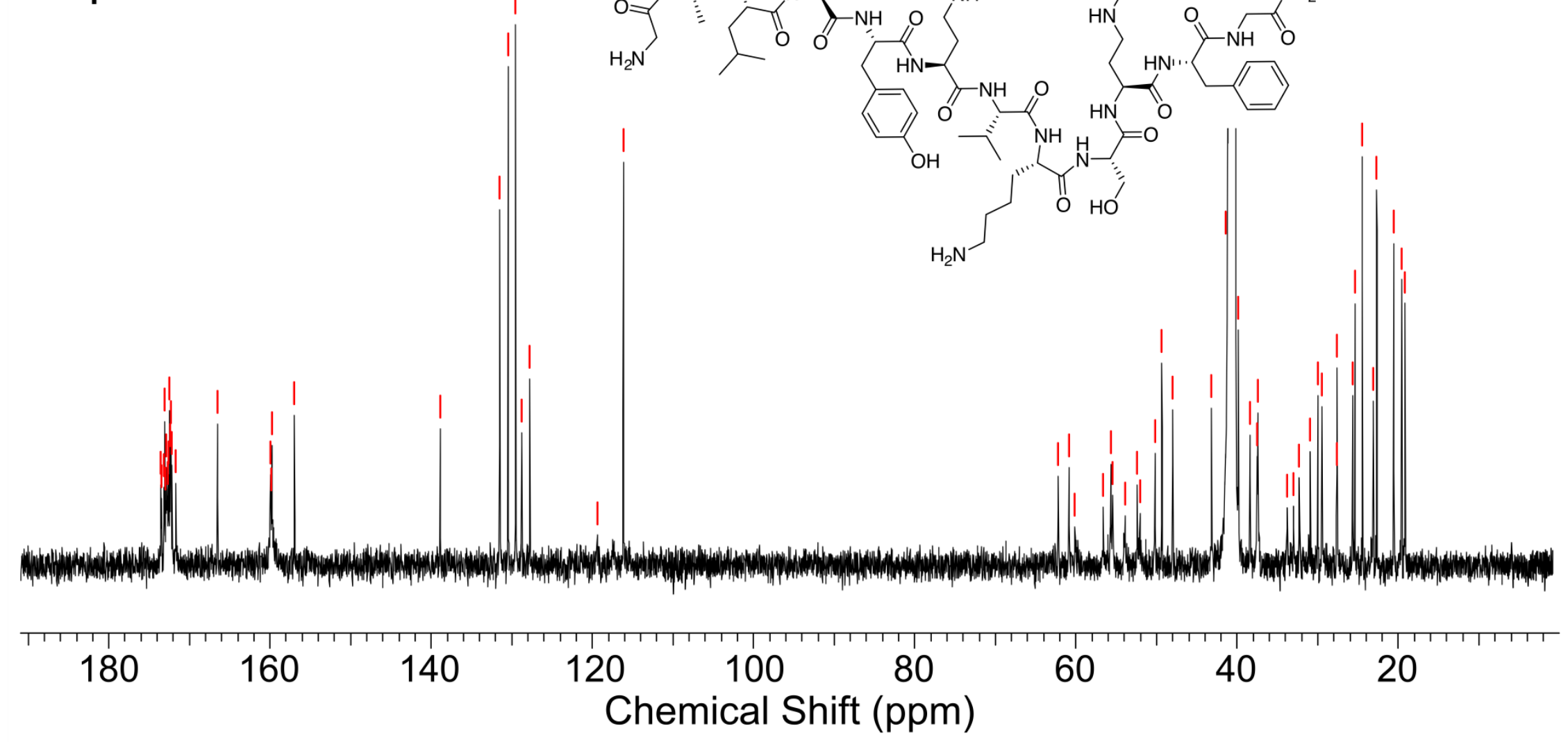

Figure S29. ${ }^{13} \mathrm{C}$ NMR (150 MHz, DMSO-d6) spectrum of peptide $\mathrm{H}_{2} \mathrm{~N}-\mathrm{GALPYE}(\mathrm{CONHNH} 2)$ VKSE(CONHNH 2$)$ FG-CONH 2 cyclized with succinic acid dihydrazide (peptide 1c). 


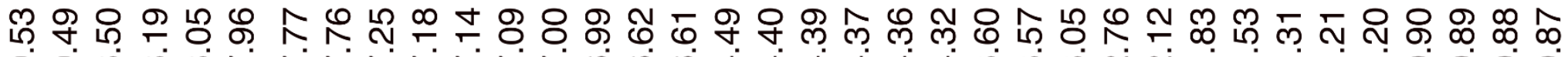

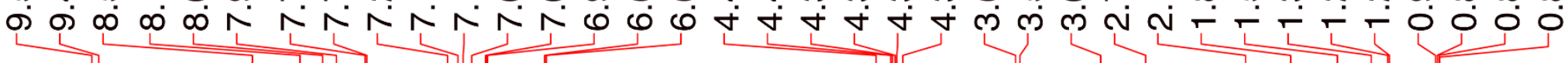

\section{Peptide 1d}

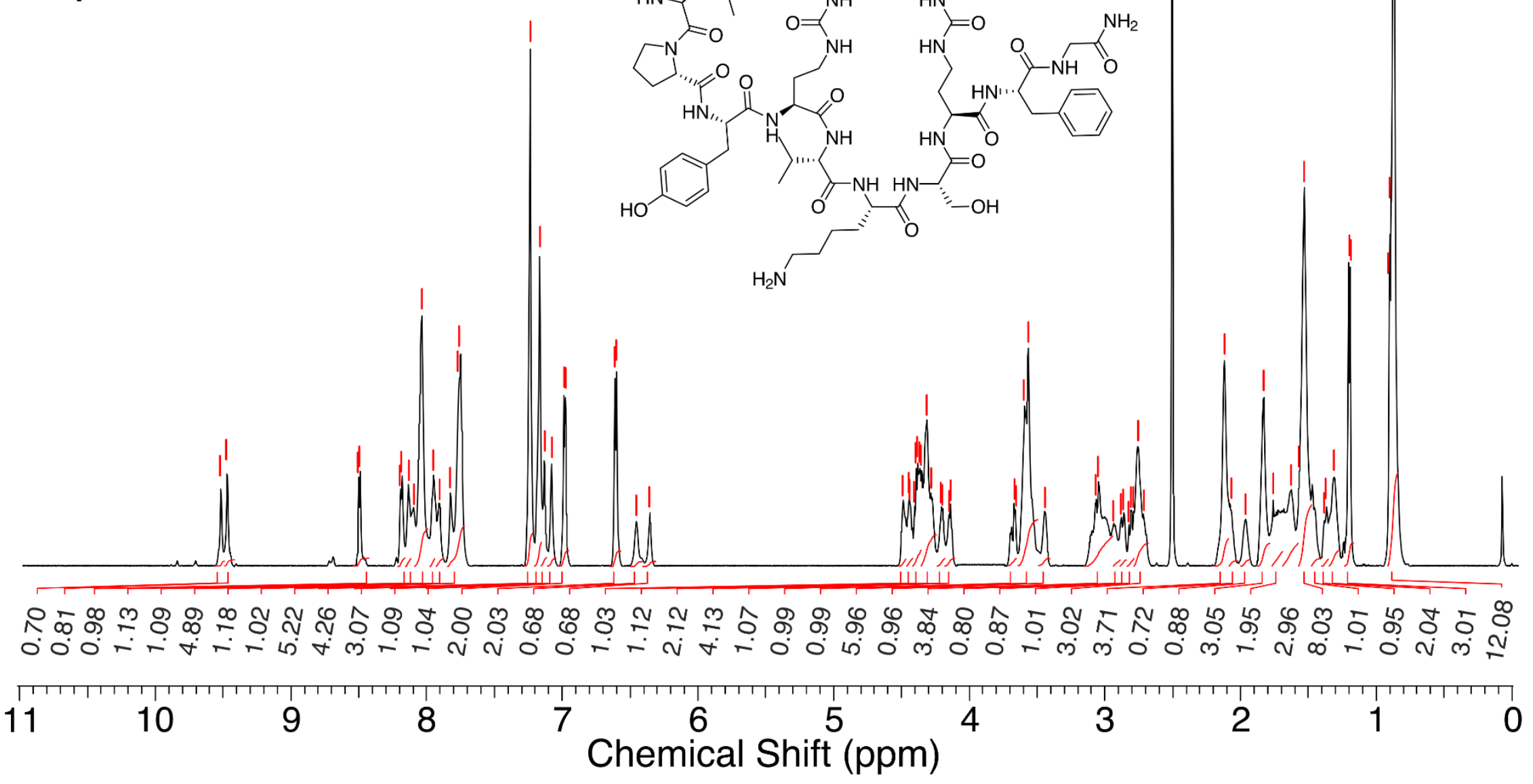

Figure S30. ${ }^{1} \mathrm{H}$ NMR (600 MHz, DMSO-d6) spectrum of peptide $\mathrm{H}_{2} \mathrm{~N}-\mathrm{GALPYE}(\mathrm{CONHNH} 2)$ VKSE(CONHNH$)$ FG-CONH${ }_{2}$ cyclized with adipic acid dihydrazide (peptide 1d). 
ธ유

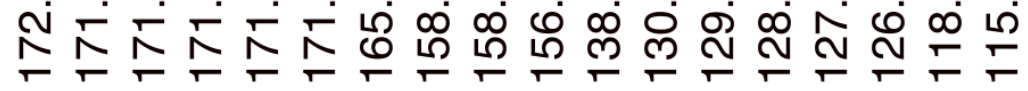

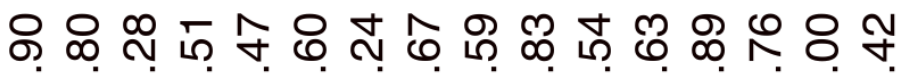

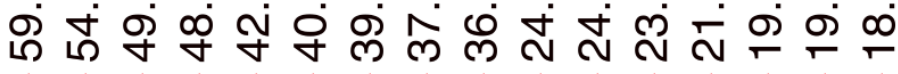

\section{Peptide 1d}

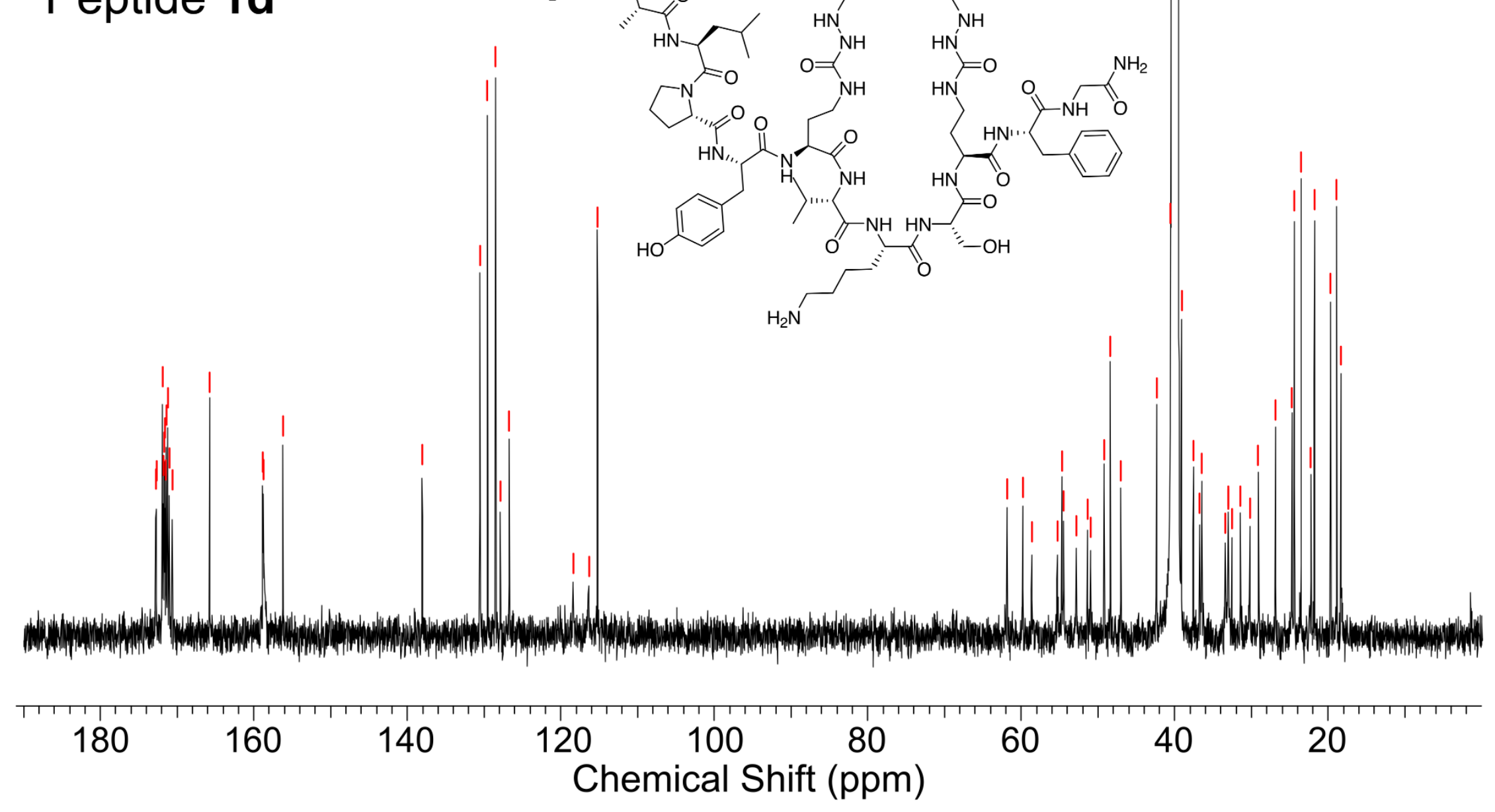

Figure $\mathrm{S} 31 .{ }^{13} \mathrm{C}$ NMR (150 MHz, DMSO-d6) spectrum of peptide $\mathrm{H}_{2} \mathrm{~N}-\mathrm{GALPYE}(\mathrm{CONHNH} 2)$ VKSE(CONHNH 2$)$ FG-CONH 2 cyclized with adipic acid dihydrazide (peptide 1d). 